\title{
El bien común, principio básico de la ley natural
}

\author{
LORENZO PEÑA \\ Instituto de Filosofia del CSIC \\ «Ne chipotons pas, il faut revenir à la loi naturelle, \\ réélargir la percée qu'elle a déjà inscrite dans nos textes.». \\ Blandine Barret-Kriegel, Les droits de l'homme \\ et le droit naturel, PUF, 1989.
}

\section{\$ 0. Introducción}

Es ampliamente conocida la rehabilitación del jusnaturalismo en el pensamiento jusfilosófico de los ültimos decenios ${ }^{1}$. Aunque posiblemente minoritario dentro de la comunidad académica de estudiosos del derecho, el jusnaturalismo ha ido ganando terreno ${ }^{2}$. Propónese el presente artículo hacerle ganar más terreno todavía, brindando una nueva versión de la teoría jusnaturalista, el jusnaturalismo de indole afirmativa, a cuyo tenor existe siempre, promulgada o no, una norma vigente en toda legislación, que es la de obrar en aras del bien común, sin que eso impida que la ley injusta promulgada por el legislador humano también esté vigente. Nuestra versión del jusnaturalismo se aparta del adagio de que la ley injusta no es ley.

Nuestro punto de partida es un texto de 1963 de Manuel Sacristán Luzón en el que se impugna enérgicamente al jusnaturalismo. Tras examinar diversas facetas de una justificación nueva del jusnaturalismo, retorno, al final del artículo, al texto de Sacristán, para responder a sus inquietudes, mostrando que el jusnaturalismo es compatible con las nobles aspiraciones que animaron a nuestro benemérito y añorado pensador hispano.

\section{\$1. La impugnación del jusnaturalismo en la pluma de Manuel Sacristán}

En un fragmento dedicado a la fundamentación filosófica del derecho ( (De la idealidad en el derecho», 1963 -reproducido en la compilación de escritos de Manuel Sacristán titulada Panfletos y Materiales, t. II, pp. 302-317), Manuel Sacristán denuncia en términos enérgicos el jusnaturalismo, desde un punto de vista materialista-histórico. Aunque el fragmento, ciertamente, no es muy explícito en delinear una propuesta elaborada, a grandes rasgos lo que viene a proponer es un tratamiento marxista del derecho -inspirado en pasajes de Marx y Engels en La ideología alemana - que haga ver cómo lo que mueve la sociedad humana (no comunista) son los intereses (de las clases sociales en pugna) y, por lo tanto, es «ideológica» -en el sentido de constituir un encubrimiento de la realidad- la pretensión de ver en una doctrina jurídica otra cosa que la expresión y la defensa de determinados intereses; las normas jurídicas vigentes serán, pues, expresiones de los intereses de clase que se hayan impuesto ${ }^{3}$.

El jusnaturalismo, al negar eso y exaltar a las normas jurídicas como reflejos o desarrollos de una nôrma ética por encima de las clases y de los tiempos (al menos en sus principios más básicos y generales), to que hace es enmascarar el auténtico 
papel del derecho en la vida de las sociedades que lo tienen - que, claro está, son las sociedades donde hay autoridad política, o sea Estado, y por lo tanto son sociedades divididas en clases antagónicas. A favor de esa tesis, Sacristán despliega varios argumentos.

Uno de sus argumentos es histórico: el jusnaturalismo ha tendido en la historia a pecar de aquello que sus adeptos achacan a los positivistas: capitular ante la fuerza. Sacristán encuentra ejemplos de eso entre los sofistas griegos y en posiciones de diversos teóricos del derecho de nuestro siglo.

El seggundo de los argumentos que formula Sacristán - sin comprometerse del todo a asumirlo - es ( $y$ tenga en cuenta el lector el año de redacción del fragmento) que el jusnaturalismo carece del rigor y la claridad propias del positivismo; elogia, en Kelsen ${ }^{4}$, su tratamiento por modo de análisis estructural de algo constatable, cual es un cuerpo de normas vigentes, poniendo entre paréntesis cualesquiera elementos inverificables como son consideraciones ético-metafísicas; el estudioso del derecho - cuando está haciendo teoría del derecho - trata de averiguar cuál es éste y cómo es, no de arengar a que sea uno u otro. La determinación de qué sea justo es un asunto extracientífico y que escapa a los métodos rigurosos de la ciencia jurídica.

El tercer argumento de Sacristán es que el jusnaturalismo es una pieza de la «involución» de la cultura «burguesa» desde la I Guerra Mundial; involución que sería retroceder a la metafísica y al idealismo, cuando la evolución del pensamiento ya los había superado. Completa esa visión de la involución reprochándoles a los jusnaturalistas: $1 .^{\circ}$, que aduzcan, a favor de su posición, la amarga experiencia de la II Guerra Mundial, «la necesidad de sanar sus heridas, según el tradicional esquema de "higiene doctrinal" tan característico de la ideología reaccionaria, que tanto tiende a decir "sano" cuando lo que importaría decir es "verdadero" »; y 2. ), que su modelo jusnaturalista no sea ni siquiera el del jusnaturalismo «de la burguesía ascendente) de los siglos XvII y XVIIr, sino el medieval-escolástico.

El cuarto y último argumento de Sacristán es que - sicndo el jusnaturalismo un legado eclesiástico de un pasado precapitalista, asumido por el sector más reaccionario de la burguesía como respuesta al ascenso del pensamiento marxista proletario (y que frecuentemente cae en «extremos de pasión legitimizadora y apologética de la sociedad existente») - lleva razón Kelsen al aducir «la indefectible apología de la propiedad privada en que desembocan todos los iusnaturalistas»; y es que los jusnaturalistas han menester de aducir algû́n contenido jurídico, por básico o general que sea, en el que hayan coincidido todos los ordenamientos jurídicos a lo largo de la historia. Al buscarlo sólo encontrarán prescripciones favorables a los intereses de las clases que hayan dominado a lo largo de la historia, como lo es la propiedad privada. Fuera de eso, cuando los jusnaturalistas alegan algún principio jurídico-natural que "siempre se haya respetado" en los códigos vigentes, sólo serían capaces de hallar alguna vacua tautología, como «el no castigo del inocente» -tautológico porque se está implí citamente definiendo al inocente como el que no ha de ser castigado, o al castigo como el tratamiento que ha de darse al no inocente-; más allá de lo tautológico, no hay principio tal que siempre haya tenido vigencia.

En suma, tras la cortina ideológica del jusnaturalismo está la apología del orden jurídico existente, aun en sus facetas más sórdidas, como discriminaciones inicuas, reglamentaciones represivas o la cconomía libre de mercado

Desde luego, Sacristán no aboga de manera clara y contundente a favor del juspositivismo, sino que incluso se queja de que para Kelsen no exista la posibilidad 
de adoptar una decisión racional respecto de valores opuestos. A la busca de una tercera posición entre juspositivismo y jusnaturalismo - que no consiguió hallar ni aun esbozar-, Sacristản, eso sí, marca su preferencia por el juspositivismo como tesis menos reaccionaria, más científica, más aceptable.

\section{\$2. Aclaración de nociones: el principio de ilación. Rechazo del eliminativismo}

Si Ebestein reprochó al derecho natural su implícita tendencia positivista - porque vendria a ser una construcción ex post facto que encumbrara al relumbrón de jusnaturalísticamente válidos principios de hecho vigentes-, cabria también - desde el ángulo de un antijusnaturalismo más radical que el del juspositivismo «tradicional» de Bentham, John Austin, Kelsen o Hart-- lamentar una tendencia jusnaturalista en el propio juspositivismo, por no haberse desembarazado de la noción misma de vigencia, la cual ha escapado a todos los análisis reductores -como los célebres de Bentham y John Austin ${ }^{5}$. Al mantener esa entidad metafísica que seria la inverificable cualidad de vigencia, el juspositivismo clásico vendría a coincidir paradójicamente con el jusnaturalismo al menos en ciertos puntos formales o estructurales, y asî vendria a comprometerse con la tesis de que hay, como mínimo, un derecho natural constituido por principios que regulan la vigencia jurídica ${ }^{6}$.

Juspositivismo (clásico) y jusnaturalismo coinciden, así, en reconocer un principio de ilación, a saber que, si está vigente una norma $\mathrm{N}^{1}$ y de ella se infiere otra norma $\mathrm{N}^{2}$, entonces también está vigente la norma $\mathrm{N}^{2}$; donde el vínculo de inferencia es una relación de deducibilidad jurídica; conque hasta el mismo juspositivismo tendrá que admitir, en consecuencia, unos principios objetivamente válidos de deducibilidad jurídica, más la validez del mismo principio de ilación, además de la existencia de esa cualidad transempírica de validez o vigencia jurídica.

Para ir desenmarañando la madeja, empecemos por aclarar algunas nociones. Muchas cosas se pueden entender por ajuspositivistno», mas aquí entendercmos esta palabra como la afirmación del principio de indiferencia, a saber: que un sistema normativo puede tener cualquier contenido o falta de contenido, o sea puede establecer como lícito o como obligatorio cualquier comportamiento o cualquier omisión y puede también abstenerse de establecer como lícita, o como obligatoria, cualquier conducta u omisión ${ }^{7}$.

En cambio llamaremos «jusnaturalismo» la negación del principio de indiferencia, o sea la tesis de que, para que algo sea un cucrpo o cúmulo de normas, ha de cumplir la condición de satisfactoriedad vigencial, o CSV para abreviar, a saber: la de o bien no tener determinados contenidos, $o$ bien tener determinados contenidos. $O$ sea, para el jusnaturalismo un sistema o cuerpo de (putativas) normas que no cumpla CSV no estará vigente -pospongo de momento el intento de dilucidar mejor la noción de vigencia. Mas la CSV será una u otra según de qué escuela jusnaturalista se trate: para unos, serả de índole negativa (carecer por lo menos de ciertos contenidos); para otros será de indole afirmativa (llevar incorporados ciertos contenidos); para otros más será alguna combinación de lo negativo y lo afirmativo.

La tesis aquí defendida será un jusnaturalismo de indole afirmativa; verosímil es que hayan de interpretarse todos los jusnaturalismos anteriores a la redacción de este articulo, sea como jusnaturalismos de índole negativa, sea, todo lo más, como mixtos, e. d. como combinaciones (yuxtaposiciones o conyunciones) de ambas índoles.

Frente al jusnaturalismo y al juspositivismo clásico, el climinativismo será la doctrina que rechace que se dê una cualidad 
transempirica de vigencia jurídica o que no acepte el principio de ilación -0 , equivalentemente, que no acepte la validez de una lógica jurídica objetiva (que sea aquella por relación a la cual se establezca, en virtud del principio de ilación, qué normas estân vigentes y cuáles no, dadas unas determinadas normas tomadas como vigentes).

Puede haber varias versiones del eliminativismo. Una sería considerar al derecho como un complejo de hechos sociales ${ }^{8}$; otra vería en el derecho un corpus de enunciados, o de actos de habla, o de situaciones que involucren enunciaciones; la cualidad de vigencia vendría, en cualquier caso, o simplemente descartada, o disuelta reductivamente en cualidades empíricamente yerificables o formalmente establecibles, respectivamente, del complejo de hechos sociales, o del sistema o cúmulo de enunciados, o de actos de habla, o de situaciones enunciativas de determinada índole ${ }^{9}$.

Sin entrar a discutir a fondo el eliminativismo, lo que en general cabe achacarle es que hace descansar demasiado en una noción explícita o implícita de convención. En efecto: en lugar de acudir a alguna noción o cualidad de validez o vigencia normativa como rasgo objetivamente poseído por determinadas normas cuando se cumplan ciertas condiciones, el eliminativismo rccurre o bien a la práctica social real o bien a rasgos estructurales formales de sistemas enunciativos.

En el primer caso se está sobreentendiendo alguna pauta de convencionalidad, o sea se toma como hecho jurídicamente relevante alguno que, en la práctica social, venga en respetarse, sea por una convenciôn explícita o sea por una implícita.

En el segundo caso - y para obviar el recurso a cualquier género de cualidad metafísica transempirica en que consistiera la vigencia - habrá que tener una concepción de los sistemas de enunciados (o de actos de habla o de situaciones enunciativas) que conciba a los vínculos entre sus micmbros (respcctivamente cnunciados, etc.) como analíticos; y la dilucidación de la noción de analiticidad suele conllevar - y hasta puede que haya de conllevarun recurso a la estipulación convencional (como en el neopositivismo vienés, que influyó en el juspositivismo de Kelsen).

Lo malo de la convención (como del pacto o contrato) es que no puede nunca fundar su propio cumplimiento. Para hacer vinculante un pacto hay que acudir a un principio supracontractual, el pacta sunt senuanda. Para que una convención vinculc, de uno u otro modo y en el sentido que sea, hace falta algún principio a cuyo tenor se hayan de respetar las convenciones; si ese principio es, a su vez, fruto de la convención -expresa o tácita-, y así al infinito, queda arruinada la fecundidad explicativa del enfoque convencionalista. (Porque puede que en la realidad se den cadenas infinitas, mas es dudoso que expliquemos nada a partir de conductas humanas de convenio si hemos de postular infinidad de tales conductas, cosa imposible por nuestra finitud.)

Así pues, vamos en lo que sigue a dar por supuesto que sí hay una cualidad de vigencia -que trataremos de desentranar-, que la vigencia de unas normas está ligada a la de otras por el principio de ilación y que hay una cierta lógica jurídica objetiva en virtud de la cual se establecen las ilaciones jurídicamente válidas.

Sentado lo cual, veremos cuán indefendible es el juspositivismo.

\section{§3. Doctrina juspositivista ${ }^{10}$}

No puede ser satisfactorio contentarse con afirmar el principio de indiferencia. Si se rechaza tal principio, entonces ya hay, para empezar, una cierta pauta de qué sea una norma o en qué estribe la validez o vigencia: por de pronto, será algo que cumpla la CSV, estribando su vigencia, entre otras cosas, en esa conformidad con la CSV. 
Mas, de adoptarse el principio de indiferencia y, por ende, descartarse toda CSV, será urgente brindar, sin demora, una indicación de en qué estribe por lo menos el que una norma sea norma, o pertenezca a un cuerpo o sistema normativo.

Lo más usual en el juspositivismo tradicional (como el de Jeremías Bentham y John Austin) era concebir las normas como mandamientos de la autoridad, o sca de aquel individuo o grupo de individuos a los que se suele obedecer y que no suelen obcdcecr a nadic (o algo similar) ${ }^{11}$.

Se ha ido erosionando poco a poco la confianza en esa tesis del juspositivismo tradicional porque se ha ido poniendo cada vez más en duda que todas las normas sean imperativas. No estă, en general, nada claro que se reduzcan sin residuo a mandamientos o imperativos las normas facultativas - las que otorgan una potestad, un derccho-, las derogativas, las que cspecifican procedimientos de producción de otras normas, etc. No es, desde luego, que el adepto de la concepción de todas las normas como mandamientos no tenga nada que ofrecer a favor de esa redueción; mas las reducciones han seguido suscitando recelos y sospechas, o han parecido cogidas por los pelos, forzadas, artificiales y ad hoc.

Se ha alegado que, a diferencia de los mandamientos o imperativos propiamente dichos -que ordenan algo a alguien (a alguien determinado)-, los promulgamientos jurídicos, aun los de carácter prescriptivo, no tienen en general ese rasgo (sino que suelen ser impersonales - no se dírigen a Fulano ni a Mengano, sino que disponen que nadie obre así o asá, o que todos obren de cierta manera); y la noción de mandamiento $u$ orden impersonal, que no se dirija a nadie en particular, resulta forzada y artificial.

Cabe enmendar entonces el juspositivismo clásico introduciendo una noción de imperatividad $\mathbf{u}$ obligatoriedad jurídica (vinculanza) $^{12}$. Tomemos tal noción como primitiva. Entonces una norma en el cuerpo o sistema de normas de una sociedad será el contenido de una declaración o proclamación solemne (promulgación), por parte de la autoridad establecida cn csa sociedad, de que es obligatoria tal o cual conducta. ( $\mathrm{Y}$, de nuevo, la determinación de quién o quiénes constituyan la autoridad se hará por criterios más o menos empíricamente verificables, como la costumbre de que se cumplan sus promulgamientos o de no cumplir ellos los promulgamicntos de otros.)

La teoría juspositivista así enmendada sostiene, pues, el principio de promulgación, a saber: es ley (o sea, es jurídicamente vinculante) sólo todo lo que (pública y solemnemente) declare obligatorio la autoridad.

Tal enmienda, sin embargo, puede que sea peor que la versión original. Ésta, al fin y al cabo, no tenía que acudir, para definir la norma, a ninguna cualidad transempírica. Cuáles sean las normas se determinaba por observación: se observan las conductas y los hábitos y se ve qué ha mandado quien tenga la costumbre de no obedecer mas sí ser obedecido; luego, eso sí, se acude a una noción de validez o vigencia para establecer que esos mandamientos explícitos son vigentes, y que también lo son cuantos se infieran de ésos por vía de deducciones jurídicamente válidas. Ahora, con la nueva versión, es menester algo más: hace faita ver que la autoridad, no es que haya ordenado o mandado, sino que ha proclamado como obligatoria tal conducta o tal omisión. $Y$ entender eso parece requerir, de entrada, una noción metafísica de obligatoriedad o vinculanza.

Podría parecer que es igual, y que disponemos de indicios igualmente objetivos y comprobables empíricamente para lo uno y para lo otro (para saber si algo es una orden y para saber si es una proclamación de vinculanza $u$ obligatoriedad). No es así. Para saber si es una orden disponemos de muchos más criterios forma- 
les, sintácticos (aunque imperfectos y falibles). Una orden o bien estará en modo imperativo, o bien tendrá una forma afirmativa mas siendo tal que, en el contexto, quepa - por la presencia de olros indicadores contextuales- determinar que es un imperativo; en este último caso (cuando no se usa el modo imperativo), se trata de una paráfrasis, o de una formulación equivalente -contextualmente- a un cierto imperativo. La noción de modo imperativo se da por conocida y patente por experiencia de la vida comunicacional.

No así con la obligatoriedad o vinculanza. No tiene ningún modo verbal especial o propio; ni hay, por lo tanto, cómo reducir declaraciones de obligatoriedad formuladas de otra manera a una formulación canónica - ya que, en este caso, no hay tal. Ni podemos meramente usar como rasero o criterio la literalidad de las palabras, ni siquiera acompañada de ajustes contextuales. Traducimos de unas lenguas a otras, de unos dialectos a otros, de unas jergas a otras, de unos estilos a otros, y conservamos la atribución de vinculanza, que se origina por una asignación autoritativa de ese rasgo a cierta conducta que efectúa, en el acto de promulgamiento, la autoridad.

Siendo, así, la obligatoriedad un rasgo metafísico nuevo, ¿podemos, para no multiplicar entidades allende lo necesario, identificarla con la vigencia? Vamos a ver: la obligatoriedad (vinculanza) ies una cualidad de la norma, o es una cualidad de la acción u omisión que la norma prescriba? Sólo si fuera lo primero podríamos identificarla con la vigencia o validez (jurídica). Mas, aunque ciertamente hay un sentido daro en el cual la norma es vinculante u obligatoria, en el sentido primario o básico lo que parece que ha de ser obligatorio es su cumplimiento, o sea la realización de la acción (o la no realización de la acción cuando lo obligatorio sea una omisión o abstención). Así, diremos que una norma en el cuerpo normativo de la sociedad $\mathrm{S}$ es la obligatoriedad de cierta conducta u omisión, $\mathrm{C}$, cuando la autoridacl de $\mathrm{S}$ ha proclamado (pública, solemnemente, etc.) que $\mathrm{C}$ es obligatoria. $Y$ diremos que la norma $N$ consiste en la obligatoriedad o no-obligatoriedad de $\mathrm{C}$, identificándose la vigencia 0 validez de $\mathrm{N}$ con esa obligatoriedad, o falta de obligatorie$\mathrm{dad}$, de $\mathrm{C}$. La norma posee su vigencia o validez como una cualidad objetiva. $\mathrm{La}$ norma no es el enunciado nomativo que la expresa, ni su vigencia es una cualidad lingüística (sintáctica, semántica o pragmática). Eso sí, hay un sentido - secundario y derivado-- de "validez» en el cual sí serán válidos los enunciados normativos (o tal vez sólo algunos de ellos).

Por otro lado, habrá que esclarecer en virtud de qué es, de hecho, jurídicamente obligatoria o vinculante una acción u omisión meramente porque lo haya dicho la autoridad (el individuo o grupo de individuos que usualmente, en esa sociedad, hagan tales proclamaciones y no ajusten su conducta a declaraciones de ese tenor por parte de otros miembros de la sociedad). $S$ in duda aquí estamos adscribiendo a la autoridad una cualidad real, y que constituye un papel lingüístico particular dentro de la comunidad de hablantes. Al igual que quien dice «Prometo hacer tal cosa» promete con ello hacer esa cosa (el suyo es un acto de habla cuya fuerza ilocucionaria hace que no pueda constituir la afirmación de una falsedad, sino que, por el mero hecho de decirlo, es verdad) ${ }^{13}$, igualmente, cuando la autoridad diga $« \mathrm{X}$ es obligatorio», $X$ será obligatorio; será ese promulgamiento un acto llocucionario que no podrá nunca ser la afimnación de una falsedad (según la versión del juspositivismo que estamos contemplando).

Mas, ¿en virtud de qué? Decimos que una prolación en modo imperativo es un mandamiento. Mas equivalentemente al imperativo está la formulación en indicativo por medio de la clấusula jusiva -una oración principal «Te mando que» más una 
subordinada en subjuntivo. Proferir «Te mando que abras el paraguas» es incurrir en un acto ilocucionario; csa prolación no puede ser falsa. Lo que hace de ella un. mandamiento es una convención lingüistica, una regla de pragmática comunicacional. Igualmente, es por una regla de pragmática comunicacional por lo que una promesa no puede ser falsa, ni una pregunta (si Cesáreo le dice a Eulalio «Te pregunto si las margaritas son coloradas» no puede ser falso que Cesáreo pregunta a Eulalio si las margaritas son coloradas).

Atribuimos a la autoridad (sólo a ella) la capacidad de hacer actos ilocucionarios promulgativos. No le atribuimos la exclusiva de decir públicamente «Decreto que...) (eso lo pueden hacer otros, mas no por ello adquieren vigencia sus promulgamientos).

¿Haremos estribar ese monopolio en una mera convención verbal? Supongamos que sí. Sea $V$ tal convención verbal. Para que pueda aplicarse, hay que presuponer una previa identificación de quiến o quiénes constituyen la autoridad; la convención que determine esa identificación no pucde ser una mera convención verbal. Si fuera una mera convención verbal lo que nos hace llamar «autoridad» al promulgador - digamos Imperator-, entonces o bien esa convención verbal es la misma que $\mathrm{V}$, o es distinta. Si es la misma que $V$, entonces la misma convención que nos hace llamar «norma» a lo promulgado por quienquiera que sea la autoridad nos hace identificar a la autoridad con Imperator; en ese caso, $V$ es la convención de llamar «vigentes* a las declaraciones de obligatoriedad de Imperator. Así, por definición, cuando decimos que en 1974 estaba vigente en España tal norma, estamos diciendo sólo esto: que lo habia proclamado Franco. Mas, si eso es así, síguense dos absurdos: $\left.1 .^{\circ}\right)$, la noción de vigencia será equívoca; y $2 .^{\circ}$ ), con la misma base podría decirse (ya que es meramente por definición, por pura convención verbal, la cual no necesita justificarse) que estaban vigentes en España en 1974 las declaraciones de D. José Maldonado o incluso las de Sancho Sánchez, vecino de Casarejos.

Mas tampoco parece acorde con el intento mismo del juspositivismo el retrotraernos a una cadena infinita de convenciones, y decir que to que erige a alguien en autoridad es su propio promulgamicnto de que él sea la autoridad; $o$ el promulgamiento de otro en ese sentido (como a Franco le confirió Cabanellas todos los poderes del Estado, y a Cabanellas se los confírió Cabanellas o no se sabe quién); o que es una cierta convención verbal arbitraria (ientre quiénes?) de llamarlo «autoridad».

En resumen, esta versión reelaborada del juspositivismo no ofrece mejores esclarecimientos que la versión clásica o tradicional, la cual, por lo menos, tenia la virtud de la claridad; pues clara era su tesis de que aquellos actos de habla de la autoridad que son fuente de ley son las prolaciones imperativas. Sin embargo, icuán insatisfactorio es reducir toda la legislación vigente a un cúmulo fortuito de órdenes proferidas por el más poderoso!

Frente a la tendencia juspositivista a hacer estribar la obligatoriedad de los promulgamientos de la autoridad en una mera convención, el jusnaturalismo puede ofrecer otra explicación, a saber: es obligatorio en una comunidad - sea la que fuereobrar a favor del bien común, estando en cambio prohibido lo que impida el bien común; mas atenta contra el bien común desobedecer los promulgamientos de quienquiera que - como resultado de las circunstancias que sean, fortuitas o nose halle investido de autoridad en esa comunidad (al menos hasta donde el cúmulo de tales promulgamientos no socave gravemente ese mismo bien común). Por consiguiente, al proclamar como obligatoria una conducta, la autoridad la hace obligatoria. 


\section{§4. Tesis jusnaturalista}

Si la tesis juspositivista es - salvo en su versión tradicional, que hoy suele considerarse superada- de problemática comprensibilidad, iqué es lo que hace en cambio atractivo al jusnaturalismo?

Hemos definido el jusnaturalismo como la mera negación del principio de indiferencia, o sea como la tesis de que un orden jurídico no puede tener cualquier contenido, sino que hay ciertos constreñimientos tales que, necesariamente, si, y sólo si, se ajusta a ellos el sistema de declaraciones a promulgamientos de que se trate, es éste realmente un corpus de leyes. No está dicho aquí si esos constreñimientos son de indole afirmativa, negativa o mixta.

La necesidad involucrada no será una necesidad metafísica, sino una inevitabilidad práctica. La inevitabilidad o necesidad práctica es menos fuerte que la necesidad metafísica (si algo es metafísicamente necesario, también es inevitable, mas no al revés), igual que la posibilidad metafísica es menos fuerte que la factibilidad o posibilidad práctica (si algo es factible, es metafísicamente posible, mas no al revés). En sendos casos la posibilidad de $X$ se define como la no-necesidad de no- $X$.

Para hacer palpable y tangible la inmediata plausibilidad del jusnaturalismo así entendido acudimos a un experimento mental: imaginemos ciertos códigos legislativos y reflexionemos sobre si sería factible que quien esté investido de autoridad los promulgara; y si, en el caso de que los promulgara, podría hacerlos acatar.

Tomemos un caso extremo. Sea $\mathrm{Z}$ el código o cúmulo de promulgamientos vigentes en determinado pais, digamos Surcolandia. En Surcolandia se produce un cambio político - concretamente una sucesión dinástica- y el nuevo monarca, Quisaldo II -quien aborrece la memoria de su difunto progenitor- promulga y sanciona la Ley de Nueva Planta por la cual quedan abrogados todos los promulga- mientos del finado rey Quisaldo I, incluyendo todos los anteriores que este último suberano había mantenido vigentes. La Ley de Nueva Planta lo que hace es, pues, prohibir sólo todo lo que estuviera autorizado al morir Quisaldo I y permitir sólo todo lo que estuviera prohibido al morir Quisaldo I. La Ley de Nueva Planta contendrá sólo todo lo que no contuviera $Z$, o sea el código vigente a la muerte de Quisaldo I.

Basta reflexionar un instante para darse cuenta de que la Ley de Nueva Planta es inaplicable y que nadie se podría tomar en serio la tarea de intentar aplicarla. Por malo e injusto que fuera $Z$, por lleno de incongruencias, aberraciones, arbitrariedades, privilegios y cxcnciones ad hoc, estaba en vigencia y era, grosso modo, acatado y cumplido en Surcolandia; la sociedad surcolandesa funcionaba, mal que bien, bajo el cetro de Quisaldo I (aunque éste fuera un cleptócrata a lo Mobutu o Duvalier). Mas con la Ley de Nueva Planta es prácticamente imposible que exista o funcione ninguna sociedad, es imposible la vida en común. Si $Z$ prohibía matar y robar a los vecinos, la Ley de Nueva Planta permite hacerlo; $y$, como $Z$ permitía no scr ladrón ni asesino, la Ley de Nueva Planta lo prohibe. $Z$ tenía que contener algunas normas que hicieran mínimamente viable la vida en común, ya que aun el acaso rapaz monarca Quisaldo I necesitaba que hubicra cierta actividad productiva para saquear a sus súbditos. Bienintencionado o no, Quisaldo II lo que hace es imposibilitar en la práctica la vida en común de los surcolandeses; manda asesinar, cometer fraude, estupro, violación, robo, etc, cada uno contra los demás. Presumiblemente manda también que la ley no se cumpla y castiga su cumplimiento (ya que seguramente Quisaldo I había inscrito en su código el precepto de que la ley se cumpliera y había prohibido, bajo castigo, su incumplimiento; la nueva ley castiga sólo todo lo que la anterior no castigaba). 
Huelgan más explicaciones. Si el código que pasa a estar vigente al iniciarse el infausto reinado de Quisaldo II está constituido por una sola ley, la Loy de Nueva Planta, ese código es tan flagrantemente inviable - tan contrario a cualquier normativa que haga factible la vida común de la gente-que no es un corpus jurídico, no es ley.

Supongamos ahora que en el vecino país de Hedibayún los jurisperitos observan con estupor las vicisitudes jurídico-políticas de Surcolandia y debaten acerca de cómo clasificar lo sucedido. La opinión mayoritaria es que la Ley de Nueva Planta no es ley; ésa es la tesis de los jusnaturalistas negativos, de quienes parten del principio tomista de que lex iniusta non est lex ${ }^{14}$; esos jurisperitos están, sin embargo, dispuestos a conceder un margen de tolerancia: (sólo) hasta cierto umbral de injusticia puede una (putativa) ley seguir siendo ley.

El segundo partido es el de los jurisperitos juspositivistas, quienes afirman que, aunque horrible, la Ley de Nueva Planta es, desde luego, ley, tan ley como cualquier otra, y que, en el orden jurídico, ha de ser obedecida (seguramente les será ilícito a los surcolandeses intentar cambiarla, mas a los ciudadanos de otros paises les será lícito enviar cartas a S. M. Quisaldo II recomendándole un cambio legislativo).

El tercer partido está representado por un solo jurisperito, Ulpiniano, según cuyo parecer la Ley de Nueva Planta es ley, mas no es la única ley vigente en ese momento en Surcolandia, Ulpiniano sostiene que lo que está vigente en Surcolandia en ese momento es un código plagado de incongruencias y hasta de supercontradicciones que contiene, por un lado, una buena parte de la vieja ley, y por el otro la Ley de Nueva Planta, por más que unas partes del código entren en conflicto con otras.

Según Ulpiniano aquellos preceptos de la vieja ley que se requieren para que haya una vida en común mínimamente llevadera siguen en vigencia, por más que también haya cobrado vigencia la abrogación de tales preceptos. $O$ sea: en Surcolandia sigue vigente, según Ulpiniano, la prohibición de asesinar, aunque también estén vigentes los preceptos de no acatar esa prohibición y de asesinar.

Ulpiniano sostiene que ningún legislador tiene potestad para suprimir la ley natural - un cúmulo de normas que hagan viable la vida común-, aunque sí otorga al legislador la potestad de promulgar la abrogación de cualquier ley, natural o no.

La diferencia entre lo uno (eliminar una ley, borrarla del corpus jurídico, e. d. suprimirla) y promulgar su revocación o derogación (abrogarla) es la siguiente: cuando la ley en cuestión es de promulgamiento facultativo del legislador (o sea, cuando, en virtud del contenido de la misma, al legislador le sea lícito promulgarla y también lícito no promulgarla), entonces la revocación suprime la ley (y aun eso, dice Ulpiniano, ha de matizarse mucho, porque no es tan radical ni automático) ${ }^{15}$. Cuando se trata de una ley vigente por derecho natural, lo único que puede hacer el legislador es mandar que quede abrogada, mas eso no suprime la ley cuya revocación se decreta, sino que sólo añade una nueva ley adicional que estipula la no-vigencia de la ley natural en cuestión; lo nuevo, con el acta de revocación, será la vigencia de la no-vigencia de esa ley natural; si de la vigencia de la no-vigencia se sigue la no-vigencia es un punto sobre el cual Ulpiniano suspende el juicio; mas no lo suspende sobre esto: aunque efectivamente la ley natural en cuestión venga así a estat no-vigente, también estará vigente.

A Ulpiniano se le reprocha que incurre en una contradicción. Él contesta lo siguiente. En primer lugar, según todos lo reconocen, el código de Quisaldo II está plagado de las más virulcntas incongruencias; y -añade-una de dos:

1) O bien la vigencia de la no-vigencia no acarrea la no-vigencia; entonces lo que 
sucederá no será ninguna contradicción mas sí esto, a saber; que el código vigente en Surcolandia en ese lapso $10^{\circ}$ ) manda que se cumpla la Ley de Nueva Planta -y que, por ende, no se cumplan en absoluto los preceptos de la ley natural-; pero también 2.) manda que sí se cumplan todos los preceptos de la ley natural; a la vigencia de ésta, la Ley de Nucva Planta habrá añadido la vigencia de su no-vigencia, mas no habrá añadido su no-vigencia.

2) $O$ bien la vigencia de la no-vigencia sí acarrea la no-vigencia; entonces sí hay contradicciones verdaderas, ya que, en tal caso, la ley natural cstará, en el presente ordenamiento jurídico de Surcolandia, a la vez vigente y no-vigente.

En segundo lugar, alega Ulpiniano que también el tratamiento juspositivista de lo acaecido en Surcolandia está comprometido a reconocer contradicciones. Porque la contradicción no viene sólo de añadir al corpus vigente los preceptos de la ley natural (lo cual acarrea el problema de la vigencia y no-vigencia simultáneas de tal ley - si es que la vigencia de la no-vigencia entraña la no-vigencia), sino que viene también del propio contenido de la Ley de Nueva Planta. Esta prescribe a X matar a $\mathrm{Z}$ y así implícitamente prohíbe a $Z$ impedir ese homicidio; mas, como también prescribe $\mathrm{a} Z$ matar a $X$ (impidiendo así el homicidio de $Z$ por $X$ ), y lo prescrito es lícito (principio de Bentham), está autorizando a $Z$ a hacer algo que, a la vez, le está prohibiendo.

EI jusnaturalismo de Ulpiniano es un jusnaturalismo de indole afirmativa. Lo que sostiene no es la (completa) no-vigencia jurídica de aquellas leyes que no respeten ciertos requisitos mínimos de justicia, sino la vigencia jurídica de aquellos preceptos que establezcan el obligado cumplimiento de csos requisitos. Él no quita nada a la ley positiva, sino que añade a ésta la validez de principios superiores. Si surge un conflicto entre diversas partes del corpus jurídico resultante, eso no impugna la teoría jusnaturalista afirmativa, ya que - según Ulpiniano, que ha leído a Bobbio- ${ }^{16}$ los cuerpos jurídicos contienen a menudo contradicciones y hasta supercontradicciones ${ }^{17}$. (Ulpiniano es, en horas libres, un lógico fuzzy y cree que, como hay grados de verdad, ha de distinguirse la mera contradicción de la supercontradicción.)

\section{\$5. Defensa del jusnaturalismo de indole afirmativa}

A la vista de la singular ocurrencia de S. M. Quisaldo II, el juspositivismo queda un tanto maltrecho. Inicialmente los juspositivistas tratan de decir que la Ley de Nueva Planta es plena y genuinamente ley y que, en el orden jurídico, no sólo no hay cómo objetarla sino que constituye, a la sazón, exhaustivamente la totalidad de la legislaciôn vigente en Surcolandia. Mas es tan obvio lo peregrino que resulta eso que pronto surgen fisuras entre los adeptos de la escuela juspositivista.

Algunos juspositivistas flaquean y empiezan a decir que no, que la Ley de Nueva Planta no es ley porque no respeta criterios estructurales o formales de coherencia normativa. A ésos se les replica que muchos sistemas normativos son incoherentes y sólo coherentizables al precio de podarlos; mas, habiendo diversas podas practicables, si sólo fuera vigente en un código el subcódigo coherente resultante de podarlo, o bien habría varios códigos vigentes a la vez y opuestos entre sí (lo cual viene a equivaler a un intercódigo incoherente), o bien habrá una determinada poda canónica, mas ícuál? Si la poda obedece sólo a reglas formales o estructurales de coherencia, entonces vale cualquiera de esas podas; si no, se está acudiendo, sin confesarlo, a una ley naturalmente vigente. 
Otros jurisperitos juspositivistas también empiezan a rehusar ver a la Ley de Nueva Planta como auténtica ley, y aducen un constreñimiento no-formal ni estructural de aplicabilidad. Se les replica que, si ese constreñimicnto quita vigencia a cualquier código que sea, en su globalidad, inaplicable, la mayoría de los códigos reales carecerán de vigencia; si se toma a cada artículo del código como una ley, entonces surge una dificulad similar a la que afronta la subescuela precedente, a saber; que hay múltiples maneras de seleccionar el subcódigo aplicable que sí tiene vigencia; y que, o bien valen todas (con lo cual el sistema de tales códigos vale también, o sea está vigente), o vale una determinada en virtud de algún criterio no arbitrario ni formal, con lo que se está incurriendo en el jusnaturalismo.

Finalmente un grupo de juspositivistas da carpetazo al problema, porque - mientras se estaba debatiendo sobre el asunto en las Universidades de Hedibayún- una rebelión de los súbditos de Quisaldo II ha derribado la monarquia en Surcolandia y se ha abolido la Ley de Nueva Planta. Los del carpetazo sostienen que sus teorías tienen como ámbito sólo el campo de ordenamientos jurídicos que puedan tener estabilidad.

Esta tesis suscita muchos descontentos, porque se les reprocha que ciñen su teoría a un terreno cuyos limites son fortuitos; y que hay que sacar lecciones de lo sucedido en Surcolandia para concebir situaciones menos extremas pero que tambiên provoquen graves problemas de esa indole; por ejemplo, ordenamientos claramente atentatorios contra el bien común, aunque no tanto como para hacer enteramente inviable la vida común de todos los miembros de la sociedad. Así un ordenamiento que otorgue a los ciudadanos que midan más de 1,80 licencia para matar a ciudadanos que midan menos de 1,65 ; no está nada claro que un código con esa prescripción tenga vigencia mientras que, don- de esté vigente, haya perdido vigencia cualquier ley que prohíba matar porque sí a otros, de la estatura que sean.

La debacle teorética de los juspositivistas ante un caso así muestra cuán poco defendible es el juspositivismo en cuanto se llega a situaciones que se salen de un ambito contingentemente y convencionalmente demarcado. Bajo la apariencia de cicntificidad y rigor, el juspositivismo es bastante débil y hasta parroquial.

¿Cuánto ha de distar del imaginario código de la Ley de Nueva Planta de Quisaldo II un ordenamiento normativo para entrar en el dominio de aplicabilidad de la teoría juspositivista? Si bien se mira, pasito a pasito, podemos deslizarnos desde ese ejemplo imaginario a otro un poco menos malo, de éste a otro, y así alcanzar los códigos reales de las sociedades humanas, con sus cosas buenas y sus cosas malas, plagados de supercontradicciones o incongruencias, que proclaman principios o reglas de justicia mas también, a la vez, prescriben o autorizan conductas claramente injustas.

No hay umbral. No hay salto cualitativo. Hay un continuum que va del código más hermoso a la Ley de Nueva Planta de Quisaldo II. Será arbitraria cualquier demarcación - dentro de ese continuo- de un campo de lo genuinamente jurídico, sólo al cual se aplicaría el tratamiento juspositivista.

Ya eso hace que se tambalee y resquebraje la construcción juspositivista. El principio de indiferencia es insostenible. La verdadera opción está entonces entre el jusnaturalismo afirmativo y el negativo.

A favor de este último está la visión del orden jurídico como coherente, o como afectado a lo sumo por incongruencias marginales, ocasionales, accidentales. Si un ordenamiento jurídico tuviera, para ser tal, que atenerse al constreñimiento de coherencia, entonces no podría contener el promulgamiento de A sin que viniera así eliminado el promulgamiento de no-A ro el 
de no-A-en absoluto, si admitimos un distingo entre negación fuerte y débil y hacemos consistir la coherencia sólo en ausencia de contradicciones fuertes o supercontradicciones).

Ahora bien, el estudio de los ordenamientos jurídicos reales revela que están llenos de contradicciones; y no raras veces aun de supercontradicciones jurídicas. Una contradicción jurídica es un par de prescripciones, una de las cuales impone como obligatorio algo que la otra prohtbe; una plausibilisima regla de inferencia de lógica juridica (el principio de Bentham de que lo obligatorio es, también y a fortiori, lícito) hace que eso entrañe que la situación en cuestión esté y no esté prohibida; otro tanto sucede para la negación fuerte, mas en este caso es verosímil que no sea irrestrictamente válida la correspondiente regla de inferencia de la lógica jurídica —esto es, que no sea irrestrictamente correcto inferir de la premisa «Es obligatorio abstenerse totalmente de $A$ s la conclusión «Está totalmente prohibido $\mathrm{A}$ », e. d. «Es totalmente obligatorio abstenerse de $A »{ }^{18}$.

Si se admite - como lo admiten hoy cada vez más autores- ${ }^{19}$ que los sistemas juridicos realmente vigentes contienen contradicciones - y hasta supercontradicciones- jurídicas ${ }^{20}$, y que es una idealización un tanto quimérica la que sólo está dispuesta, a otorgar el marchamo de «orden jurídicos a uno exento de contradicciones, entonces pierde credibilidad la concepción del jusnaturalismo de índole negativa. Éste veía con razón una dificultad en que un corpus de leyes contuviera preceptos injustos, contrarios a las reglas de buen gobierno de una comunidad; veía el problema en que, en la medida en que eso suceda, $o$ el ordenamiento en cuestión no es aplicable, o sólo lo es en desmedro del fin natural al que va orientada la actividad legislativa, lo único que justifica que haya unos grupos investidos de autoridad, a saber: que velen por el bien público. Solventaba la dificultad ol jusnaturalismo negativo tildando a los preceptos injustos de no jurídicamente válidos —al menos cuando rebasaban un cierto umbral de insoportabilidad.

Al revés de ese enfoque, el del jusnaturalismo afirmativo no tiida de inválidos -nulos, juridicamente incxistentes-a los malos preceptos, por pésimos que sean.

Lo que sostiene el jusnaturalismo afirmativo es que siempre quedan en vigor - junto a los promulgamientos injustos y por sobre ellos - preceptos más altos, que tienen vigencia en virtud de la naturaleza misma de la sociedad y de la tarea que incumbe al gobernante de velar por el bien püblico; preceptos sin cuya vigencia no es factible la vida común - dada la naturaleza humana y dada la naturaleza de las diversas acciones mancomunadas o concertadas entre individuos y grupos de la sociedad. La abolición de tales preceptos por una ley positiva no los suprime, no los invalida, no les quita vigencia, sino que a lo sumo añade su no-vigencia (aunque más probablemente añade sólo la obligación de que no tengan vigencia; y la obligación de que no tenga vigencia un precepto no entraña que el precepto no tenga vigencia, igual que la obligación de que no se robe no entraña que efectivamente no se robe; en general la obligatoriedad de A no implica la verdad de $A$, sino sólo esto: que, si se cumple la norma, entonces A).

\section{$\$ 6$. Genuina autoridad y mero poder}

Al subordinar, a lo Antigona, la vinculanza de los promulgamientos de la autoridad a la de «leyes no escritas», el jusnaturalismo, en alguna medida, es susceptible de quebrantar; 0 subvertir el orden establecido, viéndose así abocado a un distingo platónico entre mero poder y genuina autoridad, siendo esta última el poder justamente ejercido. Mas ino es ésa una estipulación arbitraria? 
Efectivamente, a diferencia del juspositivismo, el jusnaturalismo reconoce a un poder como autoridad sólo en tanto en cuanto no se aleje (excesivamente) de actuar en su papel de rector de la vida común $y$, por consiguiente, para la preservación y mejora de esa vida común.

$Y$ es que la lcy natural manda que scan privados de su poder sobre la comunidad quienes no lo usen para el beneficio de la comunidad, y en tanto en cuanto no lo usen asf. Claro que cualquier poder -en alguna medida siquiera infinitesimalhabrä de actuar con vistas al bien común, aunque sea con muchísimas restricciones; pero, cuanto más se distancie de ese principio, más propiciará su descrédito, lo cual, a largo plazo, quebrantará su estabilidad (porque, a la larga, el único modo de vencer es convencer - dado que, con todas sus limitaciones, nuestra especie es una de seres racionales) ${ }^{2 !}$.

Es contingente y fortuito que un individuo o un grupo tengan poder, o sea que manden y sean obedecidos; mas ese solo y mero hecho casual no los erige en autoridad; como no hace médico a alguien el escribir recetas en las que se prescriba el consumo de determinados fármacos, ni siquiera si el paciente le hace caso. Una autoridad impotente, en la medida en que lo sea $-\mathrm{y}$, sobre todo, cuanto más arraigada, duradera e irremediable sea la impotencia - deja de ser autoridad. Un poder injusto (cualquiera que sea su origen o su título de legitimidad real o supucsto), en la medida en que sea gravemente lesivo para el bien común, y siempre que lo sea de manera persistente y arraigada, deja también de ser autoridad. Autoridad se tiene sólo en tanto en cuanto el poder - adquirido siempre por circunstancias en último término fortuitas y accidentales- - se ejerza en aras del bien común, o al menos no se ejerza en grave y constante deterioro del bien común. Todo eso es, desde luego, asunto de grado: una autoridad puede ser menos autoridad que otra.
Tal distingo jusnaturalista entre mero poder y genuina autoridad es un aserto teorético que se basa en una reflexión sobre el cometido de la autoridad en cualquier sociedad, humana o de cualquier otra especie. Lo que lleva a una comunidad de individuos de una especie social - sea la que fucre- a tener unos jefes a los que se obedezca, la función que justifica la supremacía de esos jefes, es que su preeminencia contribuye a preservar la vida común y a mejorarla, a hacer más próspera a la comunidad o al menos evitar su deterioro. A cambio de eso, los jefes de las comunidades, humanas o no, adquieren ciertas prerrogativas ${ }^{22}$.

Muchas veces los jefes abusan y hacen del ejercicio del poder o de su propio provecho el fin de ese mismo poder; entonces hay una tendencia de las sociedades en cuestión a rebelarse. No es asunto de todo o nada. En tanto en cuanto los jefes actúan a espaldas de su tarea, dejan de tener autoridad $y$, a la larga, dejan de ser considerados como autoridad por sus subordinados, quienes acaban dotándose de nuevos jefes. En resumen, lo que hace que el jefe sólo posea autoridad hasta donde no actúe con grave perjuicio de su cometido de velar por el bien común es que la naturaleza misma de la cosa -en este caso la naturaleza de la institución autoridad - cxige atenerse al cumplimiento de esa tarea ${ }^{23}$.

Lamentarán algunos que el jusnaturalismo otorgue una licencia a los súbditos del Estado para entregarse a la subversión desobedeciendo la ley cuando crean que ésta es gravemente injusta. Eso dizque hundiria el orden jurídico y, sobre todo, haría derrumbarse el principio de seguridad jurídica ${ }^{24}$.

Mas -en esto como en lo demás- hay que distinguir las dos variedades del jusnaturalismo, porque sus resultados no son iguales (aunque sí parecidos). El jusnaturalismo de indole negativa lo que dice es que una ley gravemente injusta no tiene vigencia $y$, por lo tanto, quienes la con- 
culquen no están actuando ilegalmente. El jusnaturalismo afirmativo lo que dice es que, cuando tiene vigencia una ley gravemente injusta, tiene vigencia también una ley (natural) que obliga a no hacer lo que manda esa ley injusta; en este caso -a diferencia de lo que concibe el jusnaturalismo negativo - el súbdito o ciudadano está cogido en un dilema: vive bajo la obligación de actuar obedeciendo la ley injusta y también bajo la de actuar no obcdeciéndola (incluso, en un supuesto así, no obedeciéndola en absoluto).

Esa tensión o incongruencia del sistema jurídico resultante se resuelve, en cada caso, por una opción a favor de uno de los cuernos del dilema o conflicto de deberes; y a la larga la resuelve la sociedad alterando el orden jurídico, para ir paulatinamente eliminando cuantas leyes atenten gravemente contra la ley natural. Siempre que se opera un proceso profundo de alteración política en ese sentido invócanse principios normativos suprapositivos, cuya validez o vigencia es más alta que la de los promulgamientos circunstanciales de las autoridades de turno; principios cuya vigencia se reconoce, y no sc crea, en ese proceso.

Mas ambas variantes de! jusnaturalismo sólo hacen lícita la desobediencia cuando realmente la legislación es gravemente injusta; la mera creencia subjetiva de que se dé tal injusticia no autoriza a nada.

\section{\$7. Respuesta a algunas abjeciones}

1. ${ }^{\mathrm{a}}$ OnJeCrón.-Lo único que puede tener vigencia por encima de los promulgamientos positivos son principios o reglas puramente formales o estructurales que determinen que, si cierta norma $X$ tiene vigencia, también la tengan, o respectivamente no la tengan, determinadas otras normas $Y^{1}, Y^{2}, \ldots, Y^{n}{ }^{25}$.

RESPUESTA.-Es sumamente problemática la diferencia entre forma y contenido.
En cualquier caso, ique por eso no quede! $\mathrm{Si}$, por ejemplo, pensamos que hay una norma de derecho natural en virtud de la cual haya que actuar respetando el bien común - llamémosla el principio del bien común-, digamos que, en vez de eso, to que hay es un precepto «formal» 0 «estructural» en virtud del cual cualquier legislación que contenga una norma dada $X$, sea la que fuere, contendrá la vigencia del principio del bien común; siendo ese nexo válido por virtud de la lógica jurídica objetiva. (Además, es verdad, porque en las lógicas no-relevantes - como lo son no sólo la lógica clásica sino también muchas otras, entre ellas las propuestas por el autor de estas líneas en colaboración con Francisco J. Ausín- vale la regla uerum e quolibet: cuando tiene validez $\mathrm{A}$, tiene validez la inferencia de $A$ a partir de B, sea $B$ lo que fuere) ${ }^{26}$.

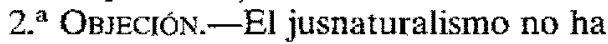
aclarado qué entidad metafísica sea ésa en la que consiste la vinculanza u obligatoriedad de una acción u omisión.

ResPuesta.-Lo único que se requiere para la verdad de las tesis jusnaturalistas es que haya alguna entidad en la que consista eso; o ni siquiera eso, sino meramente en que sea objetivamente verdad que ticnen vigencia ciertas normas independientemente de los promulgamientos variables de la autoridad. Sin embargo, he aquí una dilucidación razonable: la obligatoriedad es una cualidad objetiva de estados de cosas, una cualidad natural aunque una cuyo análisis involucra operadores modales y puede ser muy complicado; grosso modo podríamos decir, como primcra aproximación, que es obligatoria una conducta cuya omisión rebajaría el grado de realidad o existencia del entorno social en el que se produce (la diferencia entre acciones y omisiones es meramente superficial y denominativa: omitir una omisión es una acción) ${ }^{27}$. Una norma es la obligatoriedad de un estado de cosas; una norma es, a su vez, un hecho o estado de cosas. 
Un enunciado normativo formula o asevera una norma; no la crea. Sin embargo, el carácter ilocucionario de las aseveraciones de normatividad, cuando son llevadas a cabo por la autoridad, estriba en que, en ese caso particular, la declaración sí produce la verdad o existencia de la norma ${ }^{28}$.

3. Ousecrón.-La experiencia histórica muestra que no hay ninguna norma de justicia que sea común a todos los ordenamientos que han tenido vigencia.

Respuesta.-Si acaso, desde el enfoque jusnaturalista-afirmativo, lo más que revelaría la experiencia histórica es que, para cada norma de derecho natural, OA (la obligatoriedad de la acción A), ha habido algún ordenamiento jurídico que contenia la permisión de no-A (o de no-A en absoluto). Si nos desembarazamos del prejuicio consistencialista —el de que los sistemas normativos son negacionalmente consistentes, trátese de la negación de que se trate-, entonces la suma de todos esos casos a ejemplos no invalida en lo más mínimo la vigencia de las normas de derecho natural. (Ni siquiera el código de S. M. Quisaldo II; menos aún los códigos que efectivamente ha habido en este Planeta Tierra, todos ellos infinitamente menos malos que el de Quisaldo II.)

4. ${ }^{a}$ Onjeción.-Sólo los preceptos de la ley positiva gozan del respaldo de la fuerza coactiva; ahora bien, sin ese respaldo no hay ley. No existe, por consiguiente, ley natural,

Respuesta.-La fuerza pública está obligada a hacer cumplir la ley natural. Ésta goza, pues, del obligado amparo de la fuerza pública, sea ésta la que fuere (aunque sea la de un corsario que se ha apoderado de una isla, un aventurero a lo César Borja que se ha adueñado de un territorio con sus bandas de forajidos, o lo que sea) ${ }^{29}$. Lo que hace ley a una ley no es que la fuerza pública dé al legislador su amparo para que se aplique; en nuestro mundo la fuerza pública se abstiene a menudo de dar amparo efectivo al cum- plimiento de la ley, justa o injusta, a pesar de lo cual ésta sigue siendo ley, por ser un promulgamiento de la autoridad - de un grupo que, en alguna medida, es todavía autoridad. Igualmente, el que la fuerza pública no preste su amparo a la ley natural no quita a ésta su vigencia; ni empieza a estar vigente el día en que - habiéndose producido un cambio de mentalidades o de cultura- la fuerza pública o la judicatura empiezan, más o menos larvadamente, a tener en cuenta esa ley natural en cuestión -aunque sea, inicialmente, un poco a la chita callando. Lo que sucede es que entonces empieza a reconocerse esa ley natural que ya antes tenía vigencia ${ }^{30}$.

$5{ }^{a}$ Objeción.-Esta concepción de la Icy natural y este tratamicnto de la autoridad rebajan la sociedad humana al nivel de una sociedad animal, mientras que lo característico de la sociedad humana es que no actúa según la naturaleza, sino según opciones deliberadas, por voluntad, libre albedrío. La sociedad animal encuentra las normas básicas a que se ajusta en el orden natural de cosas; la humana inventa un orden nuevo por actos de creación libre, por promulgamientos.

RESPUESTA.Ciertamente el jusnaturalismo ha tendido a menudo (desgraciadamente no siempre) a reducir, en algún punto fundamental, la supuesta distancia entre el hombre y los demás animales. Ulpiano (no Ulpiniano) dijo que la ley natural es lo que la naturaleza enseña a todos los animales ${ }^{31}, \mathrm{Y}$, si bien Santo Tomás de Aquino lo acepta ${ }^{32}$, muchos jusnaturalistas de la gran tradición de la filosofía perenne lo rechazan, porque quieren que Io natural de la ley natural sea privativo de su captación racional, de la cual estarían presuntamente exentos los demás animales.

La sustentación del derecho natural articulada en este trabajo va en el sentido de la tesis de Ulpiano: la humana es una de las múltiples sociedades animales, $y$, pese a sus particulatidades, sigue las pautas 
generales. También las sociedades no humanas en las que haya individuos o grupos dotados de autoridad se rigen por el mismo principio básico de actuar en conformidad con el bien común. Al fin y al cabo el hombre no es sino un animal, pariente de los demás (pariente cercano de los demás mamíferos), aunque tenga un grado de racionalidad o inteligencia mayor que el de las demás especies (cuán grande o pequeña sea esa superioridad es otro asunto que aquí no nos incumbe). Es más, las diversas especies animales, particularmente las especies próximamente emparentadas, forman también una sociedad transespecifica, en la que quien tiene poder $-y$ ha de tenerlo con autoridadcs el hombre; conque hemos de actuar on aras del bíen común no sólo de nuestra especie, sino del reino animal del que somos parte.

\$8. ¿Cuál es el precepto básico de la ley natural? ¿El de hacer el bien o el de actuar en aras del bien común? ${ }^{33}$

El jusnaturalismo de cuño negativo tiende a concebir la ley natural como una especie de metaley, como una prescripción que obliga al gobernante a legislar en aras del bien común ${ }^{34}$. $A$ los gobernados, el jusnaturalismo negativo no les impondrá directamente obligación alguna, aunque el jusnaturalismo mixto sí les impondrá alguna - mas generalmente, eso sí, sólo algún deber de carácter vago, general- por ejemplo el principio de sindéresis, sobre el que voy a hablar en seguida.

No es éste el lugar más adecuado para debatir sobre los méritos y los deméritos de las diversas escuelas jusnaturalistas. Sin embargo, algo tenemos que decir al respecto en este punto, porque se requiere para aclarar el papel del principio del bien común. Aunque volveremos sobre el tema al final del artículo, comentando la posi- ción antijusnaturalista de Manuel Sacristán, hay ya que aclarar lo siguiente.

En la escolástica medieval $-y$, principalmente, en la renacentista y post-renacentista - se produce una discusión acerca de si el derecho natural contiene sólo prescripciones generalísimas o si también contiene preceptos detallados. Todos reconocen que hay algún precepto generalísimo que es, «como tal», de derecho natural; por ejemplo, el principio de sindéresis (hay que hacer el bien y hay que evitar el mal); y también un precepto para el legislador, el de promulgar sus preceptos en aras (sólo) del bien común.

Algunos escolásticos crcen que también son, «como tales", preceptos de derecho natural aquellos que se infieren deductivamente de los preceptos más generales. Sin embargo, nunca se aclararon suficientemente cuáles eran las reglas de inferencia deductivas de la lógica jurídica objetiva. Parece que frecuentemente se creyó que la regla básica pertinente era el dictum de omni et de nullo, o sea la instanciación (si es obligatorio hacer todo bien y evitar todo mal, y la acción $A$ es buena al paso que la acción $\mathbf{B}$ es mala, es obligatorio hacer A y es obligatorio no hacer $B)^{35}$.

La opinión que prevaleció fue la de que no son, "como tales», preceptos de derecho natural las conclusiones que, en virtud de la lógica jurídica objetiva, se infieran de los preceptos que sí scan, «como tales», preceptos de derecho natural. Así, aunque sea un precepto de la ley natural el de hacer el bien, $y$ aunque $A$ sea una buena acción, no es, «como tal», un precepto de derecho natural el de llevar a cabo A. Unos piensan que, en tales circunstancias, hacer A será un precepto de la ley natural per accidens ${ }^{36}$; otros (como Santo Tomás) piensan que la obligatoriedad natural de A será variable según las circunstancias (parafraseando lo que él dice podríamos formularlo así: en ciertas culturas, la inferencia requerida ha de darse por supuesta 
y eso hará naturalmente obligatoria a $\mathrm{A}$; mas en otras culturas no) ${ }^{3}$ ?

Así se explicaba cómo, pese a la evidencia innata que se atribuía a la ley natural, hubiera tantas discrepancias entre las diversas sociedades acerca de si era o no preceptivo tener tal o cual conducta- -digamos $\mathrm{A}$-, cuando - en virtud del dictum de omni y de la premisa adicional de que A es una buena conducta- del principio de sindéresis se infiere la obligatoriedad de A.

Sin embargo, es dudoso que tales expedientes consigan su propósito. Poco se ha aclarado con ese recurso a los ken-cuantos» aristotélicos (el distingo entre lo que es, «como tal», un precepto de la ley natural y lo que es un precepto de la ley natural pero no «como tal», o sólo per accidens; el recurso a la jerga no disipa la oscuridad del subterfugio).

Además, el principio de sindéresis encierra un equívoco de talla. $O$ bien se lee como la obligación de hacer todo lo bueno (que esté al alcance de uno) o bien se lee como el hécho de que, para cada acción buena -que esté al alcance de uno - hay que hacer esa acciôn. Lo primero es una obligación colectiva y conyuntiva, que comporta un cuantificador universal en el dictum, en el contenido de la obligación. Lo segundo es una obligación distributiva, en la que el cuantificador universal está prefijado al operador de obligatoriedad o vinculanza.

Sólo en este segundo caso se aplica la regla general de inferencia deductiva que es el dictum de omni. Para aplicar lo correspondiente a esa regla en el primer caso es menester acudir a algo así como la regla de cierre deductivo (a saber que, cuando de $X$ se sigue deductivamente $Y$, $y$ es obligatorio $X$, también es obligatorio $Y$ ). Mas esa regla de cicrre deductivo ha sido impugnada en los más recientes (y, espero, prometedores) sistemas de lógica jurídica de estos últimos años, por la doble razón de que acarrea consecuencias inadmisibles y de que se pueden obtener los resultados deseados sin esa regla - utilizando en su lugar otras reglas algo más complicadas, entre ellas la de cierre causal: las consecuencias causales de acciones lícitas son lícitas ${ }^{38}$.

En su versión distributiva es sumamente problemático el principio de sindéresis. En esa versión ese principio nos atribuye, para cada buena acción a nuestro alcance, la obligación de hacerla. Alguion ha dicho que, asi tomado, es tautológico, ya que se entiende por «buena acción" la obligatoria. Los fieles tomistas han replicado que no lo es. Mas, si no lo es, entonces tienen que no coincidir o bien las extensiones o bien las intensiones respectivas de «buenow y de sobligatorio».

Si no coinciden sendas extensiones, es que hay acciones supererogatorias - tales que es mejor hacerlas que no hacerlas, mas sin que sean obligatorias (el distingo de nuestra casuística entre consejo y precepto con el cual se tranquilizaba la conciencia de quienes no estaban dispuestos a acatar la prescripción evangélica de pobreza) ${ }^{39}$. Si hay acciones supererogatorias, no vale el principio de sindéresis en esa versión distributiva.

Por otro lado, si la diferencia entre «bueno" $y$ "obligatorio" es intensional, entonces habrá mundos posibles donde no valga - en esta versión- el principio de sindêresis, y la vigencia de éste en nuestro mundo vendrá de un arbitrario decreto divino-contrariamente a la doctrina común de que ni siquiera Dios puede, a su libre albedrío, imponer una u otra ley natural, sino que la ley natural es anterior a cualquier promulgamiento positivo, divino o humano.

Ahora bien, en su otra versión - la conyuntiva o colectiva- el principio de sindéresis es aún más obvianiente problemático, porque incluso impondrá - si hay obligaciones que se contradicen entre sí totalmente, según lo pensamos muchísimos hoy - obligaciones enteramente 
imposibles de cumplir (contrariamente al principio de factibilidad de que toda obligación incondicionalmente impuesta en un cuerpo normativo ha de ser cumplible). Además, ya sabemos que del principio de sindéresis en esta versión colectiva no se sigue ninguna obligación específica más que con la regla de cierre deductivo, claramente rechazable ${ }^{40}$.

Eso hace que el principio de sindéresis oscile entre la vaguedad, la tautología y la incumplibilidad.

Mas los propios autores escolásticos disponian de algo mejor, más claro, más aleccionador que el vago y equívoco principio de sindéresis. Era el principio del bien común ${ }^{43}$.

Ellos admiten este principio como una metaley, como una prescripción para el legislador ${ }^{42}$.

Sin embargo, examinemos un poco la regla de oro evangélica de hacer a los demás todo lo que uno quiere que le hagan a él siempre y cuando, al obrar así, no les haga a otros algo que no quiere uno que le hagan a él. Hemos combinado las dos mitades del principio - la afirmativa y la negativa - y asi el principio parece poder escapar mejor a las consabidas dificultades. $\mathrm{Y}$ nos da una pauta. Literalmente tomada, la regla de oro es demasiado exigente, y también ha de afrontar problemas sobre el alcance de los cuantificadores (lectura distributiva o lectura colectiva). Mas nos da una guia. $\mathrm{Si}$ actuamos en el espíritu de la regla de oro, procuramos en nuestra conducta un bien a los otros como lo procuraríamos a nosotros mismos, y tratamos de evitar a los demás los males que querríamos evitarnos a nosotros mismos. Actuamos, pues, en aras del bien común.

El principio del bien común no es el precepto de hacer todo cuanto sea provechoso al bien común -ni colectiva ni distributivamente-, sino el de actuar con vistas al bien común, o sea es la obligación de hacer una acción: propiciar el bien común, globalmente tomado.
Para entender mejor la significación del principio, reemplacemos el bien común de una sociedad o comunidad amplia por el bien común de una unión conyugal - de dos o más miembros. La unión conyugal es también una sociedad o comunidad, en la cual la autoridad es - pensamos hoy-ejercida por la asamblea de miembros (en el caso de número de miembros par se requerirá la unanimidad de votos, y en general el consenso). Supongamos admitido que cada miembro de la unión conyugal tiene el deber de actuar a favor del bien común del conyugio. Eso no quiere decir que tenga, para cada acción que promueva ese bien común, la obligación de efectuarla; ni que tenga la obligación de efectuar conyuntivamente todas ellas. Tiene sólo el deber de promover el bien común de la unión. De ese deber se inferirán -a tenor de la lógica jurídica objetivamente vigente- otras obligaciones. Cuáles scan éstas dependerá de cuál lógica jurídica sea objetivamente válida.

Por ejemplo, si vale el principio de cierre causal -recién considerado-, entonces, en la medida en que una acción u omisión obstaculice (propiciar) el bien común del conyugio, estarả vedada. Según otro principio plausible de lógica jurídica (el principio de no-interferencia, a saber: es ilícito impedir el disfrute de un derecho ajeno) ${ }^{43}$, estará prolibido a cada miembro del conyugio colocar a éste ante hechos consumados que le impidan actuar colectivamente en beneficio del bien común. (Pues no sólo tienen los miembros del conyugio la obligación de actuar para el bien común del mismo, sino que también el conyugio, colectivamente tomado, ticne esa obligación, y por lo tanto tiene el derecho de hacerlo - - a tenor del principio de Bentham de que lo obligatorio es, también, lícito.)

Eso sí, puede haber, y hay, conflictos de derechos y de deberes. Cuando los hay, en virtud de las diferencias de grado, unas veces un deber o un derecho sobrepuja 
en grado de vinculanza (respectivamente de licitud) al que se le opone, y alguna que otra vez están empatados.

La idea del bien común, que curiosamente no provocó sobresaltos en el pasado, ha suscitado tremendos recelos en el pensamiento individualista del siglo $\mathrm{xx}^{44}$. Se ve en ella una amenaza orwelliana de aplastamiento del individuo a favor de la máquina colectiva. Causa pavor el espantajo de los regímencs totalitarios, de las termiteras en las que el colectivo lo es todo $y$ el individuo queda anulado.

Todo eso es poco racional. En las sociedades de insectos que se presentan como cl antimodelo a evitar no se aplasta al individuo. Hay, sí, sacrificios individuales, mas sólo los necesarios en aras de la vida y prosperidad del grupo, distribuidos según pautas no arbitrarias.

$\mathrm{Ni}$ es concebible que se preserve y aumente la vida de la colectividad, que ésta sea más próspera y segura, y que paralelamente empeore la vida de los miembros de esa colectividad ${ }^{45}$. Una comunidad de desgraciados es desgraciada. Una unión conyugal de seres angustiados, que viven su vida en común como una frustración, que se sienten forzados a renunciar, por ella, a su felicidad y a su bienestar, es una unión conyugal en proceso de descomposición y decadencia; es una unión conyugal moribunda, y desde luego no próspera.

El bien comun requiere el bien de los particulares en toda la medida posible, y que los sacrificios se distribuyan equitativamente y según pautas razonables, no arbitrarias, no a voleo ni según caprichos subjetivos de los responsables; y que tales sacrificios sean sólo los mínimos indispensables; de tal sucrte que sea razonable para cada uno, aun para aquel a quien toque sacrificarse, darse cuenta de que el sacrificio es necesario y es por el bicn del grupo, de ese grupo del cual él es miembro -en lugar de ser un sacrificio de él a favor de otros miembros del grupo (que es lo que cabe a menudo reprochar a sociedades y asociaciones en las que, nominalmente por mor del bien colectivo, se aplastan legítimos derechos de los miembros: en realidad se está usando engañosamente la etiqueta del bien común y lo que se promueve es el bien de ciertos particulares en desmedro del bien colectivo) ${ }^{46}$.

\section{\$9. Respuesta póstuma a Manuel Sacristán}

Vimos al comienzo del artículo cómo Manuel Sacristân lamentaba la tendencia del jusnaturalismo contemporáneo a retornar al jusnaturalismo escolástico-medieval, retrocediendo incluso respecto a lo que a sus ojos es el jusnaturalismo progresivo (para su época) de la burguesía ascendente de los siglos XVII y XVIII.

Como tantos asertos de ese tenor en la tradición marxista, ése de Manuel Sacristán podía hacerse más fácilmente hace treinta y cuatro años, cuando la confianza en tales esquemas no había sufrido todavía un proceso de erosión de la envergadura del que ha experimentado en los últimos dos decenios. Está subyacente en tales aseveraciones un cúmulo de supuestos sobre la historia que hoy ya no son frecucntemente compartidos ni gozan del atractivo de que estaban aureolados hacia 1960. Entonces poseian aún el encanto de lo prometedor, y se creía que, con tal instrumento, se proyectaría una luz deslumbrante sobre todas las facetas de la cultura humana. Hoy sabemos que -como cualquier otro- ese esquematismo tiene sus límites, que la historia es siempre infinitamente más compleja.

Los méritos y los demétitos de cada teoría han de juzgarse, en primer lugar, independientemente de conexiones sociológicas entre sus adeptos y unas u otras clases sociales. $Y$ esos lazos suelen ser mucho más complicados, multifacéticos, contradictorios de lo que tendia a creerse dentro de los esquemas materialistas-históricos 
(aunque sea cierto que incluso tales esquemas permitían márgenes de flexibilidad y autorizaban Ia introducción de factores múltiples y contradictorios -pero al precio de complicar la explicación o el análisis y quitarle así su aparente claridad inicial).

Lo que hoy reprochamos muchísimos jusnaturalistas al jusnaturalismo predominante en los siglos xvis y xvil es la equivocada idea de un orden de naturaleza anterior - con una prioridad ontológica, no forzosamente temporal- al orden de la sociedad, surgida ésta de un hipotético pacto social. El derecho natural vendria a ser así el cúmulo de exigencias que cada hombre (macho y adulto, se sobreentendía) podría legítimamente sostener frente a los demás tanto antes del pacto cuanto después del pacto.

Es poco verosímil esa novela -que no deja de tener sus precedentes en la filosofía antigua y medieval-, aun a título de ficción ilustrativa. No ilustra nada. La inclusión del hombre individual en una sociedad es tan natural como lo es la de una abeja, un elefante o una ballena. El hombre es una especie social. El individuo nace en una sociedad, puede pasar de ella a otra o excepcionalmente (en otras épocas) tal vez hacerse un Robinson Crusoe. Lo artificial será entonces la robinsonada, y no al revés. Aparte de que es supercontradictorio pensar en un pacto social fundador del lazo social: si no preexiste en absoluto un lazo a vínculo, e. d. si no hay aún (en absoluto) sociedad, no se dan tampoco relaciones ni hay, por lo tanto, cómo concertar pacto alguno.

Tan absurdo e irracional como creer que un pensador genial resolvió todos los problemas fundamentales de la filosofía hace cincuenta, cien, trescientos o setccientos años sería creer que un gran filósofo ha podido pasar sin dejar ninguna aportación duradera y perenne. En el caso de Santo Tomás de Aquino - al humilde parecer del autor de estas líneas- su aportación permanente y definitiva es su teoría de la ley natural y el principio del bien común. No porque haya que aceptar tal cual esa teoría (aqui nos hemos apartado de ella en puntos importantes, al preferir un jusnaturalismo afirmativo al de indole básicamente negativa del Aquinate), pero sí porque, con algunas modificaciones, es una teoría válida, límpida, esclarecedora y que ayuda a dar un tratamiento jurídico que haga mejor - y no peor- la vida colectiva del ser humano.

Contestemos ahora a los argumentos de Sacristán ${ }^{47}$.

1.9) Que unos u otros filósofos jusnaturalistas hayan obrado bien, mal o regular no es un argumento decisivo ni a favor ni en contra de sus teorias, salvo que se demuestre un nexo intrinseco. No parece que en general, haciendo un balance, $\mathrm{cl}$ jusnaturalismo haya llevado a peores actitudes sociales que el juspositivismo. Según algunos historiadores de la filosofía, el jusnaturalismo estoico inspiró indirectamente varios de los más nobles movimientos sociales de la Antigüedad grecorromana. Variantes del jusnaturalismo están en la base de las revoluciones de los siglos Xvn al XIX, en el movimiento de los derechos humanos hoy, en el rechazo a los crímenes contra la humanidad, etc. Claro que de todo hay en la viña del Señor, en la jusnaturalista y en la juspositivista.

2.) La diferenciación entre forma y contenido ha perdido hoy el encanto que todavía podía atribuirle Sacristán hace treinta y cuatro años. Si hay una lógica jurídica objetiva (lo cual ha de venir admitido en el juspositivismo clásico, como el de Kelsen) ${ }^{48}$, entonces, al no valer -o valer a lo sumo con muchas relativizaciones, matizaciones y difuminaciones- la demarcación entre forma y contenido, hay un derecho natural.

3.) Lo de que el retorno a la escolástica en este o en otro punto sea una «involución» ya lo hemos comentado en los primeros párrafos de esta Sección. 
Sacristán tiene aquí una visión unidimensional, lineal, del progreso de las ideas. En realidad el verdadero avance de las ideas está plagado de tales retornos, siendo multidimensional y en espirales pluridimensionalmente entrecnizadas.

4..$^{\circ}$ Lo que el jusnaturalista necesita no es que haya un contenido normativo que haya estado expresamente reconocido en todas las legislaciones positivas (aunque seguramente lo hay), sino que se conciba a cada ordenamiento jurídico como una suma de leyes, unas de ellas promulgadas por el legislador humano positivo y otras vigentes independientemente de que sean promulgadas o no. La práctica de la evolución de las ideas jurídicas y aun de la actividad judicial lo confirma: el valor vinculante de las diversas piezas de la legislación positiva sufre vaivenes, altibajos, y frecuentemente empieza a descascarillarse y debilitarse, al paso que, una y otra vez, explicita o implicitamente, el razonamiento normativo de las asambleas legislativas y de la judicatura acaba regresando a fuentes más altas, a principios más básicos, en virtud de los cuales se invalidan (sea porque se revocan, sea porque se dejan sin aplicar) múltiples promulgamientos positivos. Es que la conciencia y la opinión públicas se han percatado, entre tanto, de que una conducta, que esas piezas legislativas imponían o toleraban, siendo un impedimento al bien común, entra en conflicto con el principio fundamental de la ley natural que todos han de acabar reconociendo y acatando ${ }^{49}$.

Sin embargo, si bien el jusnaturalista no ha menester de ninguna coincidencia entre los diferentes códigos humanamente promulgados, es sin duda fácil encontrar principios comunes a todas las Iegislaciones. Por ejemplo, no ha habido nada como la Ley de Nueva Planta de S. M. Quisaldo II. (Así la hubiera habido...)

Concluyo con una puntualización: aunque el marxismo tendió a situarse, en su aproximación al derecho, junto al juspositivismo (Sacristán no constituye una excepción, sino que sigue la regla), determinadas versiones del jusnaturalismo son (aunque tal vez pagando el precio de añadir más letra pequeña a la teoría) compatibles con el materialismo histórico.

Mas eso es -ivalga el retruécano!- de interés histórico. Lo que es relevante para el debate actual es que el jusnaturalismo tiene todavia, a su favor, muchos argumentos (y algunos de ellos nuevos) ${ }^{50}$.

\section{NOTAS}

1 Una exposición sucinta de las raíces de esc resurgimiento fue efectuada, hace ya veintisiete años, por Henri Batiffol en La Philosophie du Droit, PUF, 1970. Casi tres decenios después el avance del jusnaturalismo es todavia mayor. Sobre las raices del resurgimicnto y nuevo auge del jusnaturatismo véase de Fermândez-Galiano introduccion filosófica al derecho. Centro de Estudios Ramón Areces, $1989,5 .^{\mathrm{a}} \mathrm{cd}, \mathrm{pp} .247$ y ss.

2 Vease de H. McCoubrey The development of nathralist legal theory, Londres-N. Y., Croon Helm, 1987.

* Un andisis de la doctrina legal en el marxismo lo ofrecc H. McCoubrey, The Dovelopmunt of Naturatist Legal Theory, Londres, Croom Ileim, 1987, pp. 105 yss.
4 Véanse las siguientes obras de Hans Kelsen disponibles -entre otras- en traducción espanola: $E$ F contrato y el matado, Mćxico, Colofón, 1994; Teoría pura del derecho, Buenos Aires, Eudeba, 1994, 28." ed. (trad. del frances por Moisés Nilve); Compendio de teorín general del estado. Con un estudio pretintifar de Lais Recaséns Siches, México, Colofón, 1992 (trad. de Luis Recaséns Siches y Justino de Azcárate). Un estudio crítico de Kelsen lo ofrece Eduardo Garcia Máynez en Importancia de la teoria jurílica pura, Mćxico, Fontamara, 1994. En su Teoría pura del derecho (ed. cil. p. 62) dice Kelsen ( $y$ es un aserto que viene a compendiar su pensamicnto jusfilosófico): «Para cl conocimiento racional sólo existen intereses y en conse- 
cuencia conflictos de intereses que son resueltos favoreciendo a uno en detrimento de otro o estableciendo un equilibrio, un compromiso entre ellos. Racionalmente no es posible demostrar que alguna de las dos soluciones tiene respecto de la otra un valor absoluto y debe ser calificada de justa,

5 Vease de Rafael Hernández Marín Historia de la filosofia del derecho contcmporínea, Madrid, Tecnos, $1989,2{ }^{\circ} \mathrm{ed}$.

- Vease M. José Falcón y Tella, Concepto y fundamento de la validez del derecho, Madrid, Civitas, 1994.

7 Una crítica de la tesis de Kelsen de gue un sistema de normas juridjcas puede tener cualquier contenido lo ofrece Eduardo García Máynez, Filosofia del derecho, México, Porrúa, 1996, pp. 205-209.

s Véase de Francisco J. Ansuátegui Roig El positivismo juridico neoinstitucionalista, Madrid, Dykinson, 1996. Es posible, sin embargo, que sea exccsivo tildar a csa doctrina de «eliminativistaw; la frontera entre eliminativismo y reduccionismo es, desde luego, difusa.

* Véase de Enrico Pattaro Elementos para una teoria del derecho, Madrid, Debate, 1986. Traducción Ignacio Ara Pinilla.

sa Véase de Norberto Bobbio El positivismo jurtdico, Madrid, Dohate, 1993 (trad. R. de Asis). Del mismo autor merece en particular leerse Teoria general del derecho, Madrid, Debate, 1991 (trad. E. Rozo).

"Sobre la reducción de cualquier norma a un imperativo o una orden, véase Constantin M. Stamatis, Argumenter en droit: Une theoric critigue de l'argumentation juridique, Paris, Pubisud, 1995, pp. 173-174. (La discusión de Stamatis se centra en Kelsen, el número uno de los filosofos juspositivistas de nuestro siglo.)

is Si la obligatoriedad jurídica es, o no, la misma que la obligatoriedad élica o moral es asunto en el que no entraré en este artículo. Entre una identificación sin residuo y una tajante separación caben posiciones intermedias. Mi preferencia - he de confesarlo-- va, sin embargo, a la identificación. El hombre es -como muchos otros animales - una especie social, y ha de vivir en comunidad. Ha de existir, pues, un orden normativo que sea acatado; de lo cual se deduce -según la lógica jurídica objetiva, al menos según la propuesta de Francisco Ausin y del autor de estas lincas (vide infra) - que hay un orden normativo que ba de existir y ser acatado. ¿Cuál? Si el individuo humano le debe fidelidad y solidaridad a la comunidad que posibilita su vida, eso tambiên entraña una obligación moral de atencrse a las prescripciones que la regulen, aunquc encierren dosis de injusticia y también aunque emajen de un poder de facto [véase «Leibniz on the Allegiance due to a de Facto Powerm, por Francisco J. D. Ausin y Lorenzo Peña, Leibniz und Europa (VT.
Internationaler Letbniz-Kongress), pp. 169-176, Hannover, Gottfried-Wilhelm-Leibniz-Gesellschaft, 1994]. Claro que eso es cuestión de grado; cuanta mayor sea la injusticia global del ordenamicnto normativo vigente, menor será la obligación de abedecerlo. El no tcner en cuenta esas diferencias de grado ha solido jugar malas pasadas, conduciendo a plantear en términos de todo o nada la famosa discusión en el medio jusflosófico español sobre la obligatoriedad ética de obedecer a la Ley; vếase de Eusebio Fernández La obediencia al derecho, Civitas, 1987, especialmente pp. 91 y ss.

15 El distingo entre actos locucionarios e ilocucionarios fue introducido por J. L. Austin en sus obras How to do Things with Wonls (ed. por J. O. Urmson \& Marina Sbisá), Oxford U. P., 1976 (2." ed) -vid. pp. 109 y ss.-, y Philosophical Papers (ed. por J. O. Urmson \& G. J. Warnock), Oxford U. P., $1970\left(2,{ }^{\circ}\right.$ ed) -cap. 10, pp. 233 y ss.-. Austin partía de la noción de verbo perfomativo a ejecurtivo - uno como xprometon, "ordcno", "pregunton, *advierto", etc. Luego se distinguió un acto locucionario -el mero decirde uno ilocucionario - algo que se hace diciendo, o al decit- y se añadió un grupo más, los actos perlocucionarios. Más tarde se afinó el análisis $y$, más que hablar de actos diferentes, se habló de la fuerza ilocucionaria de los actos de habla - a tenor de varios parámetros, uno de los cuales era la cláusula principal con un verbo performativo. La teoría fue desarrollada por John Searle en Speech Acts, Cambridge U. P., 1969, cap. 3 (eThe Structure of Illocutionary Acts»), pp. 54 y ss. Esos filosofos crcian que los actos ilocucionarios carecian de valor veritativo; sufrian el prejuicio de que to que no puede ser falso no puede ser verdadero. Tal presuposición fue impugnada por otros autores; veanse Dennis W. Stampe en «Meaning and Truth in the Theory of Speech Actsw, ap. Syntax and Sentantics, vol. 3, Speech Acts, ed. por Peter Cole \& Jerry L. Morgan, Urbana: Academic Press, 1975, pp. 140; David Lewis, «General Semantics», ap. Semantics of Natural Language, ed por Donald Davidson \& Gilbert Harman, Reidel, 1972, pp. 169-218; John Lyons, Semantics, vol. 2, Cambridge U. P., 1977, cap. 16, pp. 725 y ss, especialmente p. 744. Hasta ahora no parece haber habido ningún análisis enteramente satisfactorio del verbo performativo udecretar (o sus emparentados «promulgar», "disponer», etc.) y de la fuerza ilocucionaria de las prolaciones en cuyas respectivas cláusulas principales figuran esos verbos. En cualquier caso, como quien dice -con o sin intención de cumplir- «Prometo venir mañanas dice que promete venir mañana (contenido locucionario de su prolación) $y$, de hecho, promete venir mañana (fuerza ilo- 
cucionaria de esa prolacion), lo que dice os verdad. Esa prolación no sólo no puede ser falsa sino que tiene que ser verdadera.

it La tesis de que las leyes gravemente injustas por desproporción o iniquidad potius swat uiolentiae quam leges es común en la Escolástica. Véase $S . T h, 1,2$, 94, 4; Francisco Suárez, De Legibus, 1, 9, 14 y 5s., Madrid, CSIC, 1981. Suárez distingue cuidadồamente grados, frecuencias y aspectos. Mas, por hipótesis, la Ley de Nueva Planta bate todos los records.

${ }^{15}$ Véase Luis $\mathrm{M}^{*}$ Díez-Picazo, La derogación de las leyes, Madrid, Civitas, 1990, pp. 165 y ss. (acerca de las nociones - que ese autor distingue- de vigencià, eficacia y validez). Véase tambiên de Carlos Alarcón Cabrera xDeontics between Semantics and Ontology", Sorites (ISSN 1135-1349), núm. 05 (mayo 1996), pp. 18-34 [URL: <http:/www.its,csic.es/sorites,htm>]. Alarcón estudia la concepción de la abolición o derogación como acto de rechazo. El problema del significado y de la fuerza de las abrogaciones o rewocaciones - ya ampliamente discutido en la Escolástica, p. ej., por Suárez en su magno De Legibus-está intimamente ligado a la escabrosa y debatidisima cuestión de la retroactividad legislativa, cuestión que a su vez involucra al distingo entre derechos adquiridos $y$ cxpcetativas.

16 Vénse Norberto Bobbio, aDes critères pour résoudre des antinomiesw, ap. Chaim Perelman, Les antinamies en droit, Bruselas, 1965. Según Bobbio, cuando fallan los cuatro celebérrimos principios de jerarquia normativa (cuando ni siquiera con ellos cabe determinar qué ley anule a cual), hay que escoger lat norma más justa. Esa concesión al jusnaturalismo no deja de suscitar una inquietud: si hay una pauta ohjetiva y vinculante de justicia, independiente de los promulgamientos, zpor qué no se va a aplicar también cuando no fallan esos principios - un tanto arbitrarios y artificiales- de jerarquía normativa, o el metaprincipio de jerarquía entre ellos?

"Que la consabila tetrarquia de principios reciên citada (el cuádruple dogma de nuestros jurisconsultos) no resuelve todos los problemas - aparte de que no le seria dificil a un legislador decretar la invalidez de tal cuarteto (y entonces ¿qqué pasa?) - revélanlo ejem. plos como los examinados por S. C. Coval \& Joseph C. Swith en Law and its Presuppositions: Actions, Agents and Rules, Routledge and K. P., 1986, p. 70. Un cirujano opera a un accidentado inconsciente, quien luego lo lleva a juicio por asalto. Un capitár de navio, para salvar vidas, arroja por la borda mercancias que se le han confiado, Un código civil permite, mientras que el respectivo coüigo penal prohibe, que el asesino det testador herede los bienes que le hayi legado su vic- tima. Además, los casos discutidos on la bibliografia sobre el tema de las lagunas legales involucran auténticas antinomias, si nos atenemos al principio de no impedimento (o de no interferencia) según el cual está prohibido impedir a otro ejercer un derecho (o sea llevar a cabo una acción que le sea licita). Sobre la posibilidad de contradicciones en un corpus normativo vigente, ver Jean-François Perrin, «Définir le droit...: Une pluralité de perspectives», Droirs, $10 / 1$ (1989), pp. 63-67: “L'ensemble de ces faits normalifs ne constitue pas forcément un tout cohérent. Des contradictions peuvent apparaitre* (p. 65). Sobre la tesis de que el ordenamiento juridico conticne contradicciones ver Rafael Hernández Marin, Historia de la filosofia del derecho contemporánea, p. 110. Otro ejemplo de antinomia juridica lo propone Kelsen (en El contrato y el trutado, México, Colofón, 1994); supongamos que está prohibido hollar suelo satrado, pero que también está prohibido no socorrer a un accidentado cuando se puede hacer sin riesgo propio o con poco ricsgo propio; un niño cae al agua en una zona sagrada; para rescatarlo hay que hollar suelo sagrado. Garcia Máynez (Filasofia del derecho, p. 220) comenta que no es verdadera antinomia porque no es que lo mismo estế prohibido y permitido. Sin embargo, basta con aplicar el principio de Bentham de que lo obligatorio es licito para obtener la antinomia.

${ }_{18}$ La inferibilidad en cuestión es 10 que hemos llamado en otro trabajo un *principio de benignidad (principle of mildness); véase de Lorenzo Peña y Francisco J. Ausín *Quantificational Fntitlements and Relevantoid Deontic Logic», Logitue et Analyse, 1997.

"Constantin M. Stamatis, en su libro Angumenter en droit: Une therorie critique de largumentation juridique (Paris, Publisud, 1995), pp. 253 y ss., defiende -frente a Karl Engisch- la existencia de contradicciones no solo en un cuerpo jurídico o legislativo, sino tambiên en el cúmulo de reglas o principios que inspiran su aplicación e interpretación jurisdiccionales.

20 Una luente de abundantes contradicciones juri. dicas es que una misma acción caiga bajo dos des. cripciones - por tener dos determinaciones. Bajo una de ellas es ilegal; hajo otra, legal. Por ejemplo, está prohibido causar, por malicia, daño a otro, pero permitido usar métodos de competencia comercial hicitos. La legislación suete estipular que nadie.puede ejercer un derecho cuando el único fín del cjercicio sea lesionar a otro (aunque este otro no renga ningún derecho especial a que la acción no se lleve a cabo o no surta efccto). Mas hay casos en los que la malicia no es el únjoo motivo - p. ej. casns en los que se combina la concurrencia de intereses con un mutuo despecho. Vease Judith Wagner De Cew, *Critical Legal Studies 
and Liberalism, Understanding Similarities and Differencesm, Philosoptical Topics; $18 / 1$ (primavera 1990), pp. 41-51, especialmente p. 43. En un caso así la acción es reconocida por la ley como lícita e llícita (en qué grado lo uno o lo otro habrá que precisarlo).

21 El problema de qué grado de acatamicnto tiene uno que prestar a un poder de facto guarda estrecha conexión con la cuestión que estamos aquidehatiendo. Vease aLeibriz on the Allegiance due to a de Facto Power", por Francisco J. D. Ausin y Lorcnzo Pefia, Leibniz und Europa (VI. Intemationaler Leibniz-Kongress), pp. 169-176. Hannover, Gottfried-WilhelmLetbniz-Gesellschaft, ISBN 3-9800978-7-0, 1994.

${ }^{2}$ Graco Babeuf expreso esta idea en su fórmula de que le bomheur commun est le but de la société. Y su discípulo Philippe Bwonarroti quien escribio la Conspiration pour l'égalité, dite de Babeuf, libro publicado en Ginebra en 1828 (reeditado en 1957 por las Éditions Sociales de París, en la colección "Les classiques du peuple») - dice al respecto: La loi naturelle a donné â tous un droit au bonheur»; vid. Jacqueline Russ, Le socialisme utopique français, Paris, Bordas, 1987, p. 73. Vkanse tambiên: R. B. Rose, Gracchus Babeuf, Stanford, Stanford University Press, 1978; Babeuf, Textes chosis, con introduccion y notas de Claude Mazauric, París, Éditions Sociales, 1965 (colección kes classiques du peuple»); Claude Mazauric, Babeuf et la conspiration pour légalite, Paris, Editions Socialcs, 1962.

2 Sobre la escuela jusnaturalista que toma la noción de naturaleza de la cosa como eje de su enfoque, yéase el libro de Antonio Fernández Galinno Derecho natural: Introdtccion filosofica al derecho, Centro de Estudios Ramón Areces, 1989, 5. ed., pp. 255 y ss. Véase sobre la escucla de la naturaleza de las cosas el ya citado libro de Henri Batiffol, pp. 69 y ss. Un lejano precedente de ese punto de vista -la tesis de que lo natural del derecho natural no estriba en un mero hecho de que a ella se incline el hombre por su naturalcza sino en su wcorrespondencias con la naturaleza misma de la cosa- se da en Christian Wolff: wex naturalis rationem sufficientem in ipsa honinis reramque essentia hubetz.

24 Kelsen, en su Teoria pura del derecho (ed. cit., pp. 62-63), dice; a La doctrina revolucionaria del derecho natural, que desempeña en la bistoria de la ciencia del derecho un papel relativamente oscuro, tiende al fin opuesto [al de la doctrina chásica y conseruadora del derecho natural]. Pone eu duda la validez del derecho positivo, afirmando que está en contradicción con un orden absoluto cuya cxistencia postlia. Prosenta asi al derecho bajo una luz que lo hace aparecer a veces mucho más imperfecto de lo que lo es en la realidad.»

25 La dicotomía rígida entre lo sustancialy lo formal -entre validez de contenido y validez de pura formaes también asumida por jusfilósofos que no son en rigor postitivistas, como Eduardo Garcia Máynez, quien en su Filosofia del derecho (México, Porrua, 1996), p. 313, alega - frente a Bobbio-que, si bien los principios generales de la interpretación y la integración juridica (como el principio de equidad) tienen carácter normativo, hay otros de caracter lógico-formal y ontológico-formal que no lo tienen; se da pina García Máynez una dicotomía entre to axiológico y lo (onto)logico, el orden de la verdad y el del valer (estando incluidas las normas en el segunde). Mas resultan insostenibles todas esas dicotomias rigidas: entre lo material o sustantivo y lo formal, entre el ser y cl valer, ctc.

26 Véase nuestro trabajo conjunto «Paraconsistent Deontic Logic with Enforceable Rights», que saldrá publicado en las Actas del I Congreso Mundia] de Paraconsistencia (Gante, julio 1997).

7) Una justificación y una explicación de esta dilucidación - junto con un análisis de la noción de grados de existencia o do realidad- la encontrará el lector en mì libro Hollazgos filosóficos, Salamanca, Ediciones de la Universidad Pontificia de Salamanca, 1992 cap. $1, \S 7, y$ cap. $4, \S 3$, y passim-. Se hallará un estudio más en profundidad de las nociones modales involucradas en ese análisis y de los contrafácticos relevantes en $E l$ ente $y$ su ser: un estudio logico-metafisico, Lcón, Scrvicio de Publicaciones de la Universidad de León, 1985. Séame lícito contentame aqui con este somerisimo apunte: una conducta, un orden de comportamientos, es tanto mejor cuanto más contribuya a intensificar la realidad circundante, dándole mayor entidad; por ende, a favorercer mâs realidad, más alta, mảs plena, más real (más vida, más felicidad, más armonia). Dentro de eso, hay diversas articulaciones y pattas, lo cual da lugar a conflictos de valores.

2 La tesis del jusnaturalismo afirmativo defendida en este articulo viene a coincidir con el juspositivismo en sostener una de las dos mitades del principio de promulgación, a saber: que para todo enunciado normativo $X=$ "Es obligatorio que $Z$ ", si la Autoridad dice (pública y solemnemente) $X$, cntonces $X$. Eso es rechazado por el jusnaturalismo negativo y por el mixto. En cambio, nuestro jusnaturalismo afimativo rechaza la otra mitad del principio de promulgación, a saber: si es (jurídicamente) obligatorio Z, entonces es que la Autoridad ba declarado que es juridicamente obligatorio que $Z$ ( $O$, a lo sumo, es que tal obligatoricdad se sigue - por un ncxo inferencial puramente formal- de lo que haya prescrito la Autoridad). 
3 El locus classicus de la mirada sobria que ve a un gran soberano sôlo como un pirata más poderoso es San Agustin, La Ciudad de Dios, 4, 4. A quicnes están habituados a vivir, desdc hace bastantes generaciones, en regimenes parlamentarios o presidencialistas estables tales reflexiones les suenan a referencias a lo chocante o excepcional. Pero - si miramos objetivamente la historia humana- veremos que más de 9/10 de los poderes públicos han sido piratescosi, $y$ aun del $1 / 10$ restante los que directamentc no lo han sido pucde decirse que también lo son indirectamente, porque han heredado su poder, en parte, de quienes lo habian usurpado por la fuerza (sin que sea cso óbice a la ratificación electoral o plebiscitariá, la cual no logra bortar el origen tel poder).

3) Para percatarse de que quienquiera que tenga mcdios coercitivos a su disposición incurre eo ipso en la obligación de velar por el bien común y por la equidad, fijese el lector en situaciones que se salgan de fo que solemos (en nuestra sociedad) juzgar normal y corriente. Un bandolero, un caudillo militar, un condottere -como lo han sido todos los originadores do las dinastias reinantes y de las que han reinado-, cuando tienen a su merced a poblaciones sometidas, contraen con ellas un vinculo que los constrine a velar por el bien común de esas poblaciones; la población, a su vez, gueda, en alguna medida, vinculada por la obigacion de acatar el poder de facto cn tanto en cuanto no haya mejor alternativa viable y hasta donde ese poder de facto legitime su supremacía garantizando el bien común. Véase el ya citado trabajo de Francisco Ausin y Lorenzo Peña sobre la tesis de Leibniz con relación a la obediencia debida a un poder de facto. Otro género de situaciones donde se echa de ver la corrección de nuestro principio de que la fuerza pública está obligada a hacer cumplir la ley natural son las de (supuesto) vacio legal (aquí entra la debatidisina cuestión de las lagunas en el derecho); principalmente cuando el vacío legal es singularmente grave. El 30 de noviembre de 1918 el Reglamento relativo a los tribunales populares" abrogó en la joven República Soviética de Rusja toclas las loyes pasadas. Quedó prohibido referirse a elks para fundamentar decistones de los tribunales. Los jueces actuarian según su conciencia jurifica tevolucionaria (y kqué es eso sino la ley natural, tal como la concibieran esos jueces?). Véase O. Jidkov et al., Fondements de la thourie secialiste de l'Etat et du droit, Moscú, Progrès, 1989, p. 334, Similarmente la Constitución de 1978 de Yemen del Sur revoct las leyes antiguas (que habian sido toleradas por la Constitución de 1970); ver op. cit., p. 319. Cierto que son infrecuentes tales abrogaciones masivas de la legislación preexistente; más bien los Estados que alcanzan su independencia suelen prolongar la legislación anterior en todo aquello en lo que no venga expresamente derogada (Argelia 31-12-1962, Mozambique en 1975, etc.). El vacío legal (de la legislación positiva) no exime a la fuerza pública de velar por el bien público; no la exime de su obligación de cumplir $y$ hacer cumplir la ley natural.

"Ulpiano (170-228): kitus naturale est quod natura onmia animalia docuit, Nom ius istud non humani generis proprium est, scd ommin animatium, quac in coclo, quae in terra, quae in mari nascuntur, avium quoque commune est. Hinc descondit maris atque feminac coniuncio, quam nos matrimonium appeltamus (cf. Fernândez-Galiano, p. 13; Juan Iglesias-Redondo, Defiticiones, reglas y máximas juridicas romanas, Civitas, 1986, pp. 73-74).

32 Vease de Mauricio Beuchot Derechos humanos: itspositivismo y iusnaturalsmo, MExico, UNAM, 1995 , pp. 84-85.

3 Sobre la noción de bien común en el derecho vease Hcni Batiffol, La Philosophte du Drott, PUF, $1970, \mathrm{pp} .110$ y ss.

3 Fray Luis de León (De Legibus, ed. por L. Pereña, Madrid, CSIC, 1963, pp. 21-22) dice al respecto" "1." $\therefore$ quaerimus utrum leges ordinertur in bonum communc et publictum, id est et ordinentw in id quod prodest at est utile non uni aut atteri in pariculari, sed omnibus in communi, quod bonum est praestantius et multo excellentius bono particulari. $2^{\circ}$... Si autem loquomur, non quidem de uriuerso genere hominum, sed de aliqua gente, et natione at ciutate, tunc bonum commune multitudinis est huius status tranquillas cum iustitia et opulentia. $3{ }^{\circ}$ Aduerto quod in unaquaque multitudine et communitate cst propria aliqua potestas atque uis, chitus propritum munus est bonum illus communitatis procurare et tueri; nam si huitusmodi communitates careren! huiusmodi potestate gubernatrice et procuratrice illius boni sine dubio errarent ianquam nawis sine gubernatore neque assequerentur sum bonum, finem et propositum... $1^{\text {a }}$ conclusio: onnis lex debet habese pro fine bonum publicun et commune.s

3 Fray Luis de León, De Legibus (ed. por I. Pereña, Madrid, CSIC, 1963, p. 66), debatiendo acerca de si la ley natural tiene un solo principio o varios, y frente a la tesis de Sto. Tonăs según la cual es mejor que sea uno solo - a saber bonum exscruendum, malum uitandum-, comenta (p. 66): *praefer istum principium uniuersale, quod est primum precepium legis naturae unituersalis, inuentuntur alia praecepta magis particularia, et tuate circa determinatas materias kersantur..

* Asî, ol portugues Manuel Soares - jesuita de conienzos del siglo xvi y uno de entre la pleyade de brillantes autores de la Uniwersidad de Coimbra, 
los llanados conimbricenses- [en su escrito «De lege naturali”, reproducido en F. Suárez, De Legibus $I I$, (II 1-12), Madrid, CSIC, cd. crítica bilingüe de L. Perenatet al. 1973, serie Corpus Hispanonum de Pace -edición que remite a la Biblioteca Universitaria de Coimbra, ms. 2780 , ff. 165-174] se ve abocado a una dificultad al sostener que la propiedad privada es contraria a la ley natural; trata de solventarla acudiendo a ese distingo usual en la Escolástica: 1. \% los principios de la ley natural son los preceptos cuya obligatoriedad es inmediatamente evidente, sin necesidad de demosIración; $20^{\circ}$ las conclusiones que se infieren de tales principios también son vinculantes u obligatorias, mas no con la misma evidencia. Esas conclusiones sólo serian de derecho natural per accidens: *contra vero conclusiones principiotum non sunt iuris naturalis nisi per accidens, in quantum scilicet ab isdem principiis per necessarias consequentias deducuntur fex resolutis in dicto corollario proximal*. Congue Ia propiedad común es un precepto de la ley natural pero sólo per accidens.

37 Vease el libro ya citado de Mauricio Beuchot Derechos humanos: iuspositivismo y iusnatumalismo. EI libro de Beuchot es una excelente defensa, con base histórico-filosófrea, del jusnaturalismo tomista, cuya fecundidad para la defensa de los derechos humanos demuestra de manera clara y convincente.

38 Véase el ya citado articulo de Lorenzo Peña y Francisco I. Ausin «Quantificational Entitlements and Relevantoid Deontic Logic», Logique et Anabse, 1997. Con la lógica clásica, el principio de cierre conlleva, por ejemplo, que, si el deudor ha de devolver lo prestado, entonces es obligatorio que, si no to devuelve, se confisquen todos jos bienes del acreedor. Lo que dicen los códigos civiles es muy dístinto. En caso de incumplimiento de una obligación, hay otras obligacimes deteminadas (subsidiarias) que son las que, en tal caso, han de camplirse (p. ej., si el deulor no paga la deuda, el acreedor puede exigir que esta se haga exigible en el patrimonio del mutuatario).

* Lucas 18, 22; Mateo 19, 21; Marcos 10, 21.

4 Véase el ya citado trabajo de Lorenzo Pena y Francisco J. Ausin «Quantificational Entitlements and Relcvantoid Doontic Logico, Logique et Analyse, 1997.

\$ El principio del bien común cra reconocido como la norma básica del derecho natural ya por los romanos, uno de cuyos famosos adagios juridicos era: salus populi suprema lex.

42. Como a menudo el jusnaturalismo escolástico oscila entre el meramente negativo y el mixto, hay que decir que las versiones mixtas a veces si admiten que la norma de propiciar el bien común es un precepto de la ley natural que vincula a todos, autoridades y ciudadanos particulares. Tal es el parecer de Fray Francisco de Vitoria, O. P., quien en De Pot. ciu. $-5 .{ }^{n} \mathrm{ed}$, $\mathrm{BAC}, \mathrm{p}, 157$ - dice: "In quocumque casu praeferendum est borum commune bono priuatow. Y añade que como del (buen) orden manan tranquilidad y paz, ya que compone los miembros de la sociedad como los del cuerpo de un hombre (unos en provecho de otros y todos en provecho del hombre), es menester que los individuos no menosprecien el bien público, no estén únicamente solícitos a sus ventajas particulares.

4.3 Esos (y otros) principios de la lógica jurídica están analizados y justificados en los ya citados trabajos de Lorenzo Peña y Francisco J. Ausín $\propto$ Quatitificational Entitlements and Relevantoid Deontic Logic*; Logique ef Analyse (1997), y a Paraconsistent Deontic Logie with Enforceable Rights».

44 Yéase de Bill Jordan The Common Good: Citizenship, Morality and Self-Interest, Blackwell, 1989.

45. Heinrich Henkel (citado por Eduardo García Máynez, Filosofia del derecho. México, Porrúa, 1996, pp. 486-487) sostiene que el valor supremo de los órdenes sociales es el hien común. Concibelo en una doble dimensión: anchura y profundidad. Fn anchura, abarca el bienestar de la sociedad y el de sus miembros, pero también realizaciones espirituales, éticas y artísticas, nacionales e internacionales. En profundidad, es una meta ideal de la sociedad. Dice que la concepción colectivista es fundamentalmente errónea cuando ignora que un supuesto bien común desligado del bienestar de los individuos es un disparate, pues la extinción del bienestar de estos traeria consigo la del bienestar general. (No precisa, sin embargo, cuándu ignoran eso qué colectivistas.) Para Henkel el bien común no es un elemento de la idea del derecho, el cual es un instrumento más al servicio del bien común. Garcia Máynez impugna eso, y señala que, aunque lleve razón Henkel en que el bien común es el supremo orientador de la vida colectiva, ello no es óbice para que sea también un elemento de la idea del derecho junto con la justicia y la seguridad. Según G. Máynez (p. 4\$8, ibid.) el bien común se alcanza cuando todos los miembros de una sociedad disponen de los medios indispersables para la satisfacción de sus necesidades materiales y espirituales, to mismo que para d desarrollo y perfeccionamiento de sus aptitudes.

* Una reflexión muy provechosa acerca de la relación entre valores, conductas, pautas y finalidades individuales y sus contrapartes colectivas la ofrece Andrew Levine en "Individualisms», Canadian Joumal of Phi. losophy, Suplemento al vol. 20 (Biology \& Society, ed. por M. Matthen \& R. Ware, 1994), pp. 107-131. Levine deffende convincentemente una visión superveniencial de la (cor)relación entre lo individual y lo colectivo. 
Sin usar la locución, el suyo es un valioso estudio del bien comun: "People have interests in their own well-being. But individual well-being may depend upon the existence - and perhaps also the good (however conceived) - of one's family, tribe, nation, people or state» (p. 127).

"Vimos al final del \$1 cómo Sacristán no podía compartir del todo el juspositivismo de Kelsên, con su tesis de que no hay ninguna manera de determinar racionalmente qué valores hayan de implementarse en el ordenamiento jurídico. Sacristán, como Bobbio, piensa que hubo una epoea en la que el jusnaturalismo jugo un papel de inspirador de avances político-sociales, un papel progresista, mas que eso se acabó. Tenian ambos que haber esperado un poco. Hoy dc nuevo hay un jusnaturalismo conectado con nuevas aspiraciones de avance social (derechos positivos, derechos animales, derecho a la muerte digna, etc). La levadura jusnaturalista no podia quedar para sicmpre cncerrada en los moldes del pensamiento conservador. Kelsen utacaba a wa doctrina del derecho natural [por] [...] seguir un método lógjcanente cróneo, [lo cual lel permite justificar los juicios de valor más contradictorios. Carece, por lo tanto, de interés para quien busca la verdad desde un punto de vista cicntíficom. (Teoria pura del derecho, Bucnos Aires, Editorial Universitaria, 28." ed., 1994, p. 112.) Mas con un argamento así se demostraria que la lingülistica asigue un método logicamente erróneox y que lo propio les sucede a la medicina, la palcontologia, la fisica, la historiografia, etc. Lo de que florzcan cien flores no pare. ce muy afin al espiritu positivista, al que gusta la concordancia detinitiva y sin fisuras de la inquebrantable certeza. Eran los tiempos del círculo de Viena (y muchos de los vieneses ya no creian entonces en ese dogma; hoy-después de Quine-casi nadie cree en e).

* Sin embargo, es bien sabido que el propio Kelsen se vio llevado, en su época tardía, a descartar la aplicabilidad de la tógica juridica a las normas. En su $A l l$ gemeine Theorie der Normen (Viena, Manz, 1979) admite la posibilidad de antinomias juridicas, sacando de ahí la conclusión de que no cabe ninguna lógica jumidica. Prácticamente ese enfoque no deja otra salida que la de identificar las normas con aquellos enunciados normativos que las expresan, y además literalmente citados - ni siguiera parafraseados. Ha dado lugar a una serie de polémicas y discusiones tal punto de vista del kúltimo Kelsen -que arainaria la racio. nalidad de la práctica judicial y de la abogacia. Véase, por ejemplo, el artículo de Roberto Guastini QOught-Sentences and the Juristic Description of Ruless, Ratio Juris $4 / 3$ (diciembre 1991), pp. 308-321.

4 Cada vez que la conciencia y la opinión públicas avanzan, percatándose de que el bien común $\rightarrow$ sea el precepto básico de la ley natural- demanda permitir ciertas conductas y prohibir los nbstáculos que se les solian interponer, lo que se produce $-y$ va poco at poco infiltrándose en la práctica jurisdiccional, aun con transgresiones a la retardataria lcy escrita - es un remitirse a una normatividad superior a la de los códigos. Poco a poco las prácticas bárbaras que êstos todavia mantienen van quedando obsoletas y caducas. Piénscsc en lo que se ha avanzado - a favor de la ley natural y en contra de los códigos - durante los últimos cier años en temas como: derechos laborales; derechos positivos cn gencral (a unos medios de subsistencia, a una ocupación digna, a asistencia sanitaria, a una vivienda, etc.); garantias procesales; castigos penales; derechos de niños y jóvenes; derechos fcmeninos; contracepción; interrupción del embarazo en casos justificados; derechos animales; antisegregación y antjdiscriminación; eutanasia (aunque cn esto último casi todo queda por hacer). La ley seguia a menudo siendo bátbara, cruel, inhumana, pero la práctica la iba suavizando, porque la conciencia de la gente iba descubriendo el conflicto entre esa ley promulgada y la ley natural. Yalgo similar sucede con la propiedad privada. El mismo Kelsen reconoce que, aunque la mayoria de los filosofos jusnaturalistas creyeron que la propiedad privada es una institusión de derecho natural, otros han sostenido lo contrario. En su Teoria pure det derecho (Buenos Aires, Editorial Universitaria, 28. ${ }^{*}$ ed $_{x}$ 1994, p. 112) Kelsen dice: «... cl mismo derceho natural ha sido invocado para demostrar que la propiedad priwada es contraria a la naturaleza, y que ella es la fuente de todos los malcs socialcs. Tal es la tesis de una obra publicada sin nombre de autor, que apareció en París en 1755 con el título de Code de la Nature ou le veritable esprit de ses lois (publicada por E. Dollćans, París, 1910)... Babcul, jefe de un movimiento comunista durante la revolución francesa, la cita frecuentementer. La obra en cuestion fue escrita por Morelly aunque atribuida cquivocadamente a Diderot.

so Mucho agradezco a Luis Fernández Moreno sus criticas y observaciones a un borrador de cste articulo que me han ayudado para la redacción final del nismo. 